\title{
Has the internet fostered inclusive innovation in the developing world?
}

Citation for published version (APA):

Paunov, C., \& Rollo, V. (2014). Has the internet fostered inclusive innovation in the developing world? UNU-MERIT. UNU-MERIT Working Papers No. 084

Document status and date:

Published: 01/01/2014

Document Version:

Publisher's PDF, also known as Version of record

\section{Please check the document version of this publication:}

- A submitted manuscript is the version of the article upon submission and before peer-review. There can be important differences between the submitted version and the official published version of record.

People interested in the research are advised to contact the author for the final version of the publication, or visit the DOI to the publisher's website.

- The final author version and the galley proof are versions of the publication after peer review.

- The final published version features the final layout of the paper including the volume, issue and page numbers.

Link to publication

\footnotetext{
General rights rights.

- You may freely distribute the URL identifying the publication in the public portal. please follow below link for the End User Agreement:

www.umlib.nl/taverne-license

Take down policy

If you believe that this document breaches copyright please contact us at:

repository@maastrichtuniversity.nl

providing details and we will investigate your claim.
}

Copyright and moral rights for the publications made accessible in the public portal are retained by the authors and/or other copyright owners and it is a condition of accessing publications that users recognise and abide by the legal requirements associated with these

- Users may download and print one copy of any publication from the public portal for the purpose of private study or research.

- You may not further distribute the material or use it for any profit-making activity or commercial gain

If the publication is distributed under the terms of Article $25 \mathrm{fa}$ of the Dutch Copyright Act, indicated by the "Taverne" license above, 


\title{
UNITED NATIONS \\ UNIVERSITY
}

\author{
UNU-MERIT
}

\section{UNU-MERIT Working Paper Series}

\section{\#2014-084}

Has the internet fostered inclusive innovation in the developing world? Caroline Paunov and Valentina Rollo

Maastricht Economic and social Research institute on Innovation and Technology (UNU-MERIT) email: info@merit.unu.edu | website: http://www.merit.unu.edu

Maastricht Graduate School of Governance (MGSoG)

email: info-governance@maastrichtuniversity.nl | website: $\underline{\text { http://mgsog.merit.unu.edu }}$

Keizer Karelplein 19, 6211 TC Maastricht, The Netherlands

Tel: (31) (43) 388 4400, Fax: (31) (43) 3884499 


\section{UNU-MERIT Working Papers}

ISSN 1871-9872

Maastricht Economic and social Research Institute on Innovation and Technology, UNU-MERIT

\section{Maastricht Graduate School of Governance MGSoG}

UNU-MERIT Working Papers intend to disseminate preliminary results of research carried out at UNU-MERIT and MGSoG to stimulate discussion on the issues raised. 


\title{
Has the Internet Fostered Inclusive Innovation in the Developing World?
}

\author{
Caroline Paunov* \\ OECD
}

\author{
Valentina Rollo** \\ Graduate Institute, Geneva
}

Version: 10 December 2014

\begin{abstract}
Based on 50,013 firm observations covering 117 developing and emerging countries, this paper shows knowledge spillover effects from industries' use of the Internet boosted the average firm's productivity and innovation performance. We document that industries' "digitization" had heterogeneous impacts: results from quantile regressions indicate that the most productive firms benefited much more than others. Wider Internet adoption rates were also of larger benefit to singleplant establishments, non-exporters and firms in remote locations, particularly to the most productive among these firms. Overall, we document that the Internet can play an important role to support inclusive innovation, conditional on firms' "absorptive" capacities.
\end{abstract}

Keywords: Information and communication technologies (ICTs), Internet, innovation, productivity, firm heterogeneities, informal businesses, developing countries

JEL Codes: O33, O14, O12, D22, L6, L8

*Corresponding author: Caroline Paunov, Directorate for Science, Technology and Innovation, OECD, 2, rue André Pascal, 75775 Paris Cedex 16, France. Email: caroline.paunov@oecd.org and caroline.paunov@ gmail.com. Phone: 0033 (0) 145 2490 40. ** Valentina Rollo, Graduate Institute of International and Development Studies, Maison de la Paix, Chemin Eugène-Rigot 2, Ch1202, Geneva, Switzerland. E-mail: valentina.rollo@graduateinstitute.ch. Valentina Rollo gratefully acknowledges support from the SNF, Project Number PDFMP1_135148. The authors would like to thank Richard Baldwin, Nicolas Berman, Ana Margarida Fernandes, Dominique Guellec, Eric J. Bartelsman and participants of the 2014 ABCDE Conference, the Inter-American Development Bank's internal seminar and the $7^{\text {th }}$ Annual Conference of the Academy of Innovation and Entrepreneurship for valuable comments. The findings expressed in this paper are those of the authors and do not necessarily represent the views of the OECD or its member countries. 


\section{Introduction}

The uptake of the Internet and mobile technologies has been ubiquitous (ITU, 2014) changing not merely the cost but the way knowledge is exchanged. Increasingly large sets of knowledge, "big data", can be more easily transmitted, if desired, to a large global audience and within seconds. This is not a trivial matter: the fundamental change in knowledge transmission opportunities may raise opportunities for firms and other economic agents to benefit from knowledge generated by others. This is critical for innovation, which builds on new combinations of existing ideas. Consequently, wider exposure to different ideas can raise economies' innovation performance (Arthur, 2007). What is more, these knowledge spillovers are critical for economic growth by generating increasing returns (Romer, 1986; Krugman, 1991; Grossman and Helpman, 1991). In addition, Internet-enabled knowledge spillovers can make even more of a difference to firms with weaker connections to good "offline" knowledge networks. For instance, businesses in isolated locations operate in a weaker regional business ecosystem and may have more to gain from knowledge made available via the Internet. The regional knowledge network will provide fewer knowledge inputs than that of firms in less isolated regions. The Internet may in this way help promote more inclusive democratic innovation, i.e. the widening of the group of innovators beyond the often very small group of innovating firms in developing countries (Paunov, 2013). However, taking advantage of knowledge is not straightforward and requires firms to have absorptive capacities (Cohen and Levinthal, 1989). If firms are not able to use newly available knowledge, then better access to knowledge via the Internet will be meaningless to their overall performance. To the extent that weak innovators lack those capacities, the Internet's impact on making innovation more inclusive may be more limited.

The paper provides evidence on the question whether industries' use of the Internet results in spillover effects on firms' productivity and innovation performance. It focuses explicitly on heterogeneous impacts across firms' of different characteristics and productivity levels. Our evidence is based on 50,013 firm observations across 117 developing and emerging countries for 2006-2011. The analysis exploits information on industries' adoption of the Internet as a tool for communicating with suppliers and clients. Our empirical specification relies on a comprehensive set of firm controls as well as industry and country-year fixed effects. This approach ensures our coefficient of interest industries' use of the Internet - does not pick up industry-specific effects or differences across countries and years. That is, our identification exploits within country-year differences in the adoption of the Internet across industries. An industry's adoption of the Internet is unlikely to be affected by an individual firm's productivity and innovation performance and, therefore, the risk of reverse causality is low. We use quantile regressions to test whether productivity differences - as proxy for differences in "absorptive capacities" - affect the beneficial impact of the Internet.

We find that industries' adoption of the Internet has positive impacts on firms' labor productivity and their investments in equipment. We also identify modest impacts on the likelihood of firms to seek quality certificates and patents. The evidence is robust to various tests such as including 
context control variables and using alternative definitions to measure Internet adoption rates that are most relevant to the firm. Moreover, we show that, on average, the "digitization" of their industries provided larger gains to firms that did not export, that were not part of multi-plant establishments and that were operating in remote locations. By contrast, we do not find that smaller firms benefited more than larger firms. Quantile regression results also show that the more productive firms gain much more from the "digitization" of their industries, while firms with productivity levels below the $50^{\text {th }}$ percentile had few benefits. Our evidence of larger benefits for average non-exporting firms and single-plant establishments holds only for the most productive among them. Similarly, we find larger payoffs for the most productive smaller-sized firms relative to larger businesses.

Several policy implications arise from our analysis. First, our evidence points to the existence of spillover effects from industries' adoption of the Internet. These gains, which did not depend on firms' own investments, provide support for public policies aimed at fostering industries' use of the Internet. Second, the fact that the Internet benefited more firms that commonly engage less in innovation points to the Internet's potential for facilitating more inclusive innovation. This is critical for many emerging and developing countries, where often only a very small number of firms innovate. Internet-based business intelligence platforms and exchange forums can increase benefits further. Such business intelligence services allow for a targeted analysis of firms' scientific and technological environment based on exploiting information available on the Internet. Third, the fact that "catching up" opportunities arise only for the better performing firms indicates the importance of policies aimed at building firms' absorptive capacities. If such shortcomings are not addressed, then the wider knowledge access opportunities from the Internet will continue to leave out the weakest performers. In spite of widespread adoption, this could create a new divide related to the effective use of knowledge transmitted via the Internet.

Our paper makes several contributions to the debate about the impacts of ICT in developing and emerging economies. First, to the best of our knowledge, this is the first study to provide cross-country evidence of spillover effects of the Internet adoption by industries in developing and emerging economies on firms' productivity and innovation performance. Using data for 2006-2011 is critical as the effective adoption of the Internet has only gained maturity in those years and, therefore, data covering prior years would underestimate impacts. Second, our study expands on the previous analyses by explicitly focusing on whether the Internet facilitated more inclusive innovation. It explores two dimensions: $i$ ) whether firms with more limited access to "offline" knowledge networks benefit more from their industries' Internet adoption and ii) whether impacts differ across firms' productivity distribution. We adopt quantile regressions to understand if "average" effects as captured by conventional estimation techniques hide differences in impacts across firms of different productivity levels.

The paper contributes to several strands of the literature. First, it relates to the work on the impact of ICT investments on firms' productivity. Extensive research, conducted at industry and firm 
levels, finds positive impacts of ICTs (e.g. Bartel et al., 2007; Jorgenson, 2001; Jorgenson and Vu, 2005, Oliner and Sichel, 2000 and Stiroh, 2002). However, complementary investments, including in improving management capacities, are often critical to maximise benefits from the Internet (Black and Lynch, 2001, 2004; Bloom et al., 2012; Bresnahan et al., 1996, 2002; Brynjolffson and Hitt, 2000). Studies on the impacts on innovation have also identified positive effects (see, for example, Spezia, 2011, for an analysis of eight OECD countries). As for developing and emerging countries, a World Bank report identifies positive correlations between a simple measure of ICT use and various firm performance indicators, such as employment and innovation for the early 2001-2003 period (World Bank, 2006). Several country studies focus on how firms' ICT use relates to their productivity and, in some cases, their innovation performance (e.g. Commander et al., 2011, for Brazil and India, Motohashi, 2005, for China; UNCTAD, 2008, for Thailand; ECLAC, 2011, for Argentina, Chile, Colombia, Peru, and Uruguay). Our paper also relates to papers that discuss opportunities for ICTs to stimulate the "democratization of innovation". Many of these case studies have identified opportunities for very small firms and entrepreneurs and the informal economy at large (e.g. Donner and Escobari, 2010; Kaushik and Singh, 2004 and Aker and Mbiti, 2010 among others). Few papers focus explicitly on the question whether the Internet might stimulate more inclusive innovation processes. An exception is the study by Ding et al. (2010) who find the Internet facilitated the inclusion of women scientists and those working at non-elite institutions in collaborative research. ${ }^{1}$

Second, our paper contributes to the literature that has documented that knowledge spillovers, i.e. gross social returns to knowledge investments, by far exceed private returns (Bloom et al., 2013; see Audretsch and Feldman, 2004, and Keller, 2004 for overviews of the literature on international and geographic dimensions of knowledge spillovers). Foreign multinationals in particular may be a valuable source of knowledge spillovers for domestic firms. However, while some studies identified positive spillover effects (e.g. Haskel et al., 2007), much of the evidence points to limited direct effects (see Görg and Greenaway, 2004 for an overview). One of the explanations is firms' lack of "absorptive" capacity to make use of newly available knowledge (Kokko, 1994; Kokko et al., 1997; Girma, 2005). To the extent that firms' capacities can be an obstacle, Internet-enabled knowledge access benefits may also be lower and, in particular, restrain the extent to which it promotes inclusive innovation processes. Another relevant finding from this literature relates to the "boundaries" of knowledge spillovers. While research finds geographic boundaries continue to matter, there is an ongoing debate about whether the Internet will lead to the "death of distance" (Cairncross, 1997, see discussion in Section 2). If such "boundaries" can be overcome, then opportunities for increased Internet-enabled knowledge spillovers rise.

The remainder of the paper is organized as follows. Section 2 discusses the conceptual framework while Section 3 presents the data we use for our analysis. Section 4 introduces the empirical framework. Section 5 describes the results of the analysis while the final section concludes.

\footnotetext{
${ }^{1}$ A related study by Agrawal and Goldfarb (2008) finds that the adoption of Bitnet, an early version of the Internet, disproportionately benefited middle-tier universities' collaboration with leading universities.
} 


\section{Conceptual Framework}

\subsection{Firms' Uptake of the Internet}

Many firms in developing and emerging countries have adopted the Internet to support their operations. Evidence from our dataset, which is described in Section 3, shows that by 2006-2011 a large share of firms used the Internet to communicate with clients and suppliers. Even among firms in low-income economies $47.3 \%$ had adopted this communication tool. Moreover, while small firms were less active users than larger businesses, their uptake was of $44.5 \%$ (Figure 1). Informal businesses were also active users of mobile telephony. Table 1 shows that particularly for the African businesses in our sample $76.2 \%$ used mobile telephony in 2009-2010. ${ }^{2}$ This is remarkable as more than two third of these firms had experienced power outages and more than one in four firms did not have electricity.

Industries uptake of the Internet was not homogeneous and varied substantially across different countries' sectors. In the textiles industry, for instance, the share of firms using the Internet for communication ranged from $21 \%$ in Nigeria, $25 \%$ in Indonesia and $33 \%$ in Pakistan to $100 \%$ in Argentina, Costa Rica and Peru. In the retail and whole sector, the same shares range from $20 \%$ for Uzbekistan or 30\% for Angola to near-to full adoption in Hungary (96\%) and Estonia (99\%). Figure 2 shows substantial dispersion existed. The food, garment and service industries - i.e. retail and wholesale trade as well as hotels and restaurants - show evidence of a sizable number of weak adopters and of large dispersion. The chemicals and pharmaceuticals industry was very much a "frontrunner" with high adoption rates across different countries in the world. In conclusion, the statistics reported show wide but varied uptake of the Internet as a means of communication in the developing world. ${ }^{3}$ The question on corresponding returns of adoption we address in this study is, therefore, pertinent.

\subsection{Knowledge Spillovers and Firms' Innovation Performance}

Industries' adoption of the Internet as a means of communication can stimulate firms' innovation performance by improving the diffusion of knowledge. More than other economic activities, innovation and technical change depend on access to new knowledge. This is because unlike physical property, knowledge grows over time based on the existing stock of knowledge. There exists, that is, much benefit from "standing on the shoulders of giants". To the extent that innovation depends on connecting to diverse sources of knowledge, the increased availability itself can provide new opportunities for innovations (Arthur, 2007). This is well illustrated by an analogy of firms drawing balls from an urn that holds knowledge relevant to their activities. The Internet supports wider access to a larger number of balls from that urn. Improved communication among members of an industry supports learning about new technologies, influencing the rate of technology adoption (e.g. Conley

\footnotetext{
${ }^{2}$ The average is obtained for the available informal firm surveys of Angola, Botswana, Burkina Faso, Cameroon, Cape Verde, the Democratic Republic of Congo, Ivory Coast, Mali and Mauritius.

${ }^{3}$ As described in the notes of Figure 2 the number of country observations differs across industries.
} 
and Udry, 2010 and references therein). ${ }^{4}$

As for the types of knowledge relevant to firms' activities, information from clients, suppliers and competing firms can strengthen firms' innovation performance in different ways. First, clients' preferences and needs may offer better information about market opportunities for new products and services. The associated reduction in market risks might lead to more innovation efforts as uncertainty is a major obstacle to firms' investment decisions (see Collard-Wexler et al., 2011). Users might also be more involved, and by providing feedback - a widely used system to identify bugs in software allow for new product and service developments. ${ }^{5}$ Second, learning from suppliers about downstream developments of technologies, which determine the technical feasibility of introducing innovations, can also spur innovation. Third, knowledge about competitors' practices is directly relevant as a source for learning about alternative production techniques and product innovations. ${ }^{6}$

Finally, there are other sources of benefit from the adoption of the Internet on firms' productivity and innovation performance. This includes the use of ICTs to improve the evidence-base in firms' decision-making (e.g. Brynjolffson et al., 2011), which can also support firms' innovation performance. These factors, however, are more closely related to the firms' own adoption of the Internet and related ICT investments rather than to their industries' adoption rates. We leave these questions aside in this study and deal with the question of Internet-enabled knowledge diffusion only.

\subsection{Knowledge Spillovers and the Internet}

The empirical evidence points to positive impacts of knowledge spillovers on firm performance (cf. Audretsch and Feldman, 2004, and Keller, 2004). Knowledge lends itself to such spillovers since, once created, it can be replicated and disseminated at virtually no cost, and consequently benefit more firms (Arrow, 1962). The Internet has contributed to reducing those dissemination costs even more; the challenges such replication has posed to the entertainment industry illustrate its capacity. At the same time, there are possible limitations to how the Internet can contribute to stimulating spillovers: only codified knowledge can be transmitted while other types of knowledge - often referred to as "tacit" knowledge - cannot. The challenge of establishing "trust" when it comes to exchanging critical knowledge will also require face-to-face interactions (Leamer and Storper, 2001). The importance of "tacit" knowledge is one of the reasons why geographic proximity may continue to matter (Krugman, 1991, Audretsch and Feldman, 1996). However, ICTs have also reduced barriers for transmitting such knowledge. This includes the possibility to transfer large amounts of information in ways that increasingly match "proximity", including, for instance, videoconference opportunities.

Potential benefits from Internet-facilitated knowledge spillovers, if they exist, do not specifically depend on individual firms' use of the Internet. Instead wider knowledge diffusion results

\footnotetext{
${ }^{4}$ This could notably affect productivity and equipment investment and to some extent the adoption of quality certificates, but will not be as relevant for patents.

${ }^{5}$ User involvement might in some cases stimulate innovation, notably if it leads to co-innovation with users (von Hippel, 2005; Bresnahan and Greenstein, 1996).

${ }^{6}$ However, knowledge from competitors might be less easily obtained as these have an interest in keeping information secret from their direct competitors (see e.g. Javorcik, 2004).
} 
from a critical mass of industries' firms relying on the Internet. For the same reason, it is also not the firm's own use of the Internet that matters most. Firms that do not use the Internet could benefit from better knowledge diffusion within their industry by other means (such as gatherings of business associations, recruitment of new staff or face-to-face contacts with other firms). The question whether the Internet facilitates knowledge spillovers is, therefore, distinct from the questions how firms' own investment and uptake of information and communication technologies has benefited their performance (cf. references of relevant studies provided in the introduction).

\subsection{The Internet as a Potential Facilitator of Inclusive Innovation}

The benefits from the "digitization" of their industries may be heterogeneous across firms. One reason is that the "value-added" from Internet-enabled knowledge spillovers may be larger for some firms than for others. That is because, coming back to the analogy of the urn introduced above, the increase in access to additional balls will be bounded by the full number of balls available. That is, as firms' access to knowledge networks improves, the knowledge the firm can access will eventually be equivalent to the relevant existing knowledge. This is because the adoption of the Internet as a means of communication facilitates wider access to knowledge but only contributes in the long run to expanding the stock of knowledge itself. To the extent that the characterization describes well the contributions of the Internet, it will be the case that, all else equal, firms connected to already rich offline knowledge networks have fewer gains from the Internet. By contrast, those with limited access to knowledge networks will have more to gain.

Several firm characteristics relate to their access to knowledge networks and may consequently determine heterogeneous impacts. One condition is about firms' connections abroad. Exporters or foreign-owned firms might have less to gain from Internet-enabled knowledge spillovers. The reason is that they already access foreign expertise, a critical source for advanced technologies, particularly for firms in developing and emerging economies (Coe and Helpman, 1995; Fagerberg, 1994; Freeman and Soete, 1997). For these firms, the wider opportunities of knowledge access provided by the Internet might not offer as much value as to firms with no such connections. Another condition is firms' geographic location. Those firms based in more remote locations have less dense local networks, and, therefore, the quality of the knowledge available to them could be lower. With the Internet's ability to cross distances more effectively, these firms may stand to benefit more than firms in larger agglomerations (and with richer knowledge sources). The question has been subject to analysis for more than a decade (e.g. Cairncross, 1997, Friedman, 2005, Forman and Van Zeebroeck, 2012). Forman et al. (2014) conclude from their analysis of Internet investment and patenting indicators across counties in the United States, that "the Internet has the potential to weaken the longstanding importance of the geographic localization of innovative activity" (p. 5).

In addition, plants size may also make a difference. Smaller-sized firms have by definition smaller internal knowledge networks and often have more modest R\&D investments. This is partly because of fixed cost-spreading advantages and agglomeration benefits larger firms can benefit from 
with regards to $R \& D$ (Cohen, 2010). Advantages to size are likely reinforced over time as returns to R\&D will disproportionately reward larger firms (Klepper and Simons, 2005). They might consequently benefit less from digitization. There is evidence confirming that smaller firms reap larger spillover benefits (cf. Acs et al., 1994). The same reasoning holds potentially for plants that are part of multi-plant establishment as they have more important internal knowledge networks and undertake more knowledge investments within the firm.

Finally, informal businesses may also be among those with larger knowledge gains. These businesses face more constraints for accessing a variety of business services, have fewer resources to engage in knowledge networks and are often disconnected from formal businesses. "Dual economy" structures reduce "direct" contacts and participation in networks. The Internet may, therefore, be particularly relevant. There is some evidence to show ICTs provide benefits to informal businesses: case studies have shown ICTs helped break information barriers (e.g. Jensen, 2007; Muto and Yamano, 2009). Muto and Yamano (2009) find mobile networks benefited farmers' position on markets of perishable goods in rural Uganda. Farmers in regions further away from urban centers benefited more. Country case studies have also shown that micro enterprises, including those operating in the informal sector, tended to benefit in their business activities (e.g. Duncombe and Heeks, 2002, on Botswana, Donner, 2004 and 2006, on Rwanda, Esselaar et al., 2004, for a survey of 13 African countries).

\subsection{Knowledge Spillovers and "Absorptive" Capacities}

While better access to pieces of knowledge can support firms' productivity and innovation efforts, firms need to have the capacity to deal with the knowledge they gain access to. Weaknesses in firms' capacities have been identified as major factors limiting knowledge spillovers (cf. Görg and Greenaway, 2004). The reason why indigenous capacities are critical is that technology has a "tacit" component that cannot be transferred easily. Knowledge as is might be inappropriate in specific firm contexts unless adjustments are done via "localized learning by doing" (Atkinson and Stiglitz, 1969). Several empirical studies confirm how in-house capacities complement access to knowledge (Hu et al., 2005, Kokko, 1994, Kokko et al., 1997). This factor points to another possible source for heterogeneous effects: positive impacts for the average firm may hide substantial heterogeneities as the most productive firms can likely benefit more from knowledge spillovers.

\subsection{Testable Hypotheses}

In conclusion, the discussion regarding characteristics of knowledge spillovers and opportunities provided by industries' adoption of the Internet suggests the following hypotheses for the empirical analysis: 
- First, we analyze whether the use of the Internet as a tool for communication by industries has positive impacts on firms' productivity and innovation performance. That is, we test for Internetenabled knowledge spillover effects.

- Second, we examine whether the Internet has heterogeneous impacts depending on characteristics that affect the quality of firms' knowledge networks. In other words, we test for differences in effects across $i$ ) exporting and non-exporting firms, ii) firms located in larger and smaller agglomerations, iii) single- and multi-product firms and $i v$ ) differently sized firms. We also test $v$ ) whether informal businesses benefited from their industries' adoption of the Internet.

- Third, we investigate whether different capabilities influence the impact of industries' adoption of the Internet on firms' productivity and innovation performance. We do so by testing for differential impacts change for firms at different productivity levels.

\section{Data}

We use the second improved wave of the World Bank Enterprise Surveys (WBES) for our empirical analysis. The WBES is uniquely suitable to providing robust quantitative evidence on aggregate and heterogeneous impacts of ICTs on firms in developing and emerging countries. Our analysis uses information for 50,013 firm observations across 117 countries for 2006-2011. This sample is a selection from the full 65,285 firm observations available, excluding observations without information on firms' labor productivity and industries' use of the Internet for communication purposes. ${ }^{7}$ Table 2 summarizes data coverage across world regions, manufacturing and service industries, firm size categories, years, and country income levels. The WBES have been widely used, including in Almeida and Fernandes (2008), Beck et al. (2005), Fisman and Svensson (2007) and Paunov (2014) among many others. The WBES collect information in each country on a representative sample of formal firms in the non-agricultural sector. The selection of firms in each country is done by stratified random sampling. Dethier et al. (2011) give a comprehensive review of the dataset and a comprehensive list of studies that have used these data.

Interestingly for our purposes, the WBES include information on firms' actual use of the Internet rather than simply investment information which says little about actual use. In particular, the dataset has information on whether firms used email to communicate with suppliers and customers. The indicator is suitable for our purpose since it directly relates to whether the Internet is used for communication purposes. That is, it relates to the exchange of knowledge with clients and suppliers, which, as discussed above, is critical for firms' acquisition of relevant knowledge for their business activities. The dataset also has information about whether firms owned websites, which we use as a proxy variable of firms' investments in Internet technologies. ${ }^{8}$ We add this variable systematically to

\footnotetext{
${ }^{7}$ The routines used by the authors to clean the original dataset are available upon request.

${ }^{8}$ Other information (including for what purposes the Internet is used) is also available but only for a small selection of firms.
} 
our regressions in order to capture knowledge spillover effects rather than returns to private investments in ICTs.

The surveys also cover basic information on firms (sales, employment, ownership type, and export performance). The information allows computing labor productivity and we also have information on firms' investments in equipment, a critical factor for firms' innovation activities, as well as firms' patent and quality certificate ownership. With regards to patent information, unfortunately only a small set of observations is available as the variable is not collected across all surveys we combine in our analysis.

Finally, in order to see to what extent the Internet supports the "democratization of innovation", we also assess impacts on firms in the informal economy. This is critical the more so since its size is substantial, particularly in developing and emerging economies (Schneider et al., 2011). We use the informal firm dataset, provided by the WBES, which covers 1,557 firms for 7 countries $^{9}$ in 2010 , to explore the uptake of mobile phones. As the nature of the data is different from the main WBES dataset, we use the data separately from the analysis of the main dataset, applying, however, the same methodology applied to the main WBES dataset.

\section{Analytical Framework}

To study the impact of industries' adoption of the Internet on firms' innovation and productivity performance, we adopt the following baseline estimation:

$$
Y_{i c t}=\alpha+\beta_{1} * I C T_{j c t}+\gamma * X_{i c t}+\lambda_{j}+\lambda_{c t}+\varepsilon_{i c t}
$$

where $Y_{i c t}$ is a measure of firm $i$ 's labor productivity or its innovation efforts, i.e. whether the firm owns a quality certificate or patent and its equipment investment. $I C T_{j c t}$ is an indicator of industry $j$ 's uptake of using email to communicate with clients and suppliers (excluding firm $i$ 's uptake) ${ }^{10}$ in country $c$ in year $t . X_{i c t}$ is a full set of firm-level control variables which are discussed in Section 5. Coefficient $\beta_{1}$ is our variable of interest as it identifies spillover effects. We test for spillovers by obtaining a measure of country-year industry adoption, identified across 15 different industries. ${ }^{11}$ The set-up is similar to that used in Acs et al. (1994) or Haskel et al. (2007) to study impacts of industries' R\&D or FDI intensities, to provide an example for each. Seker (2012) and Dollar et al. (2006) apply a similar approach to identify impacts of business conditions on firm performance. We also add $\lambda_{j}$ and $\lambda_{c t}$, respectively a set of industry and country-year dummies. In other words, our identification strategy exploits differences in industry's adoption of the Internet across countries while controlling for characteristics specific to industries or countries in any year.

\footnotetext{
${ }^{9}$ The countries for which we use data are Angola, Argentina, Botswana, the Democratic Republic of Congo, Guatemala, Mali and Peru.

${ }^{10}$ The ICT measure is built for industries (by country-year) with at least 10 observations, excluding the firm $i$ 's own response.

${ }^{11}$ We test whether our results hold for more narrowly defined industry knowledge-spillovers, such as including only industries that are geographically close to the firm, as part of our robustness.
} 
Two challenges affect the analysis of the impacts of firms' ICT use on firm performance: $i$ ) endogeneity - while IT might support innovation performance, it could also be the case that more innovative firms rely more on IT; in fact it is very likely that most productive firms self-select into such activities, and ii) omitted variable biases (i.e. the fact that there might be other unaccounted factors that effectively drive the relationship picked up in the regressions). Both factors point to a positive bias on coefficients of ICT uptake leading to an overestimate of the contribution of ICTs towards firm performance as we expect more productive firms to be more likely to adopt ICTs. This, however, is less of a challenge for our analysis, which focuses instead on the adoption of the Internet at the industry level. It is unlikely that firms' innovation and productivity performance has a direct impact on their industry's adoption of the Internet. To avoid potential endogeneity concerns, firm $i$ 's own use of the Internet is excluded from the industry average we compute. Also, as our variable of interest is aggregated, measurement error is less of a concern. In addition, we address omitted variable biases by introducing industry and country-year fixed effects in addition to firm-level controls. Country-year fixed effects allow isolating potential differences across countries in specific years. This includes government policies with possible impacts on firms' productivity and innovation performance. Controlling for industries is also important because certain industries are more technology-intensive than others, so that allowing for the variation across industries may bias results. We also include an extensive set of controls in our regressions. Appendix Table 2 describes each of the variables in detail.

In order to test for possible heterogeneous effects across firms we estimate the following modified model:

$$
\begin{array}{r}
Y_{i c t}=\alpha+\beta_{\text {Type } 1} *\left[I C T_{j c t} * \text { Type }_{i c t}\right]+\beta_{1} * I C T_{j c t}+\gamma * X_{i c t}+\lambda_{j}+\lambda_{c t}+\varepsilon_{i c t} \\
Y_{i c t}=\alpha+\beta_{A D V 1} *\left[I C T_{j c t} * T y p e A D V_{i c t}\right]+\beta_{D I S 1} *\left[I C T_{j c t} * T y p e D I S_{i c t}\right]+ \\
\gamma * X_{i c t}+\lambda_{j}+\lambda_{c t}+\varepsilon_{i c t}
\end{array}
$$

where Type $_{i c t}$ indicates certain firm characteristic (as notably firm $i$ 's size) and TypeADV $V_{i c t}$ and TypeDIS $_{i c t}$ are dichotomous variables of firm characteristics (for instance, whether the firm is an exporter, TypeADV $V_{i c t,}$ or not, TypeDIS $\left.S_{i c t}\right)$.

Moreover, we apply quantile regressions in order to assess whether impacts differ based on firms' labor productivity. Quantile regressions can be expressed in the general form (Koenker and Basett, 1978) $\operatorname{Prod}_{i c t}=x_{i c t}{ }^{\prime} \beta+\varepsilon_{i c t}$ with $Q_{\theta}\left(\operatorname{Prod}_{i c t} / z_{i j c t}\right)=z_{i j c t}{ }^{\prime} \beta_{\theta}$, where $z_{i j c t}$ includes all explanatory variables as in (1), (2) and (3). Estimating $\theta$ from 0 to 1 gives the entire conditional distribution of Prod $_{i c t}$, conditional on $z_{i j c t}$ (Buchnisky, 1998). In other words, using quantile regressions shows the effect of industries' Internet adoption at different levels of the conditional productivity distribution, rather than at the conditional mean of our dependent variable. Other empirical applications of quantile regression techniques include, for example, Yasar and Morrison Paul (2007), Fattouh et al. (2005) and 
Coad and Rao (2008). We analyze differential impacts on other innovation variables, interacting our variable of interest, industries' adoption of the Internet, with above or below median firm productivity at $t-3$ or, respectively, the quartile of the distribution of productivity at $t-3$ the firm was part of.

Finally, to estimate equations for the average firm we apply ordinary least squares regressions for the analysis of labor productivity and equipment investment and logistic estimation models to assess the impacts of industry Internet adoption on quality certificates and patents. Robust standard errors clustered by country, industry and year level are applied systematically following the procedure to account for our aggregate variable of interest (Moulton, 1990).

\section{Results}

\subsection{Baseline Results: ICT-enabled Spillovers on Firm Productivity and Innovation Performance}

First, we test whether the wider diffusion of ICTs leads to knowledge spillovers and results in higher firm productivity and improves innovation performance. Panel A of Table 3 shows regression results of Equation (1) for labor productivity: column (1) reports results for industries' use of the Internet with industry and country-year fixed effects. We find a positive significant effect. We progressively add controls at the firm level. These include firms' employment and age (column 2), indicators of public ownership and whether the establishments are part of multi-plant establishments (column 3) and controls for whether the firm has connections abroad (i.e. foreign-ownership and exporter status) (column 4). We also add proxies for managerial quality and access to finance (column 5). Consistently with the prior literature, we find that these factors are positively correlated with firms' productivity except for public ownership which is negatively correlated with firms' productivity. We also find firms' own investment in ICTs, proxied by a variable indicating whether firms owned a website (column 6), affects labor productivity positively. The latter finding is consistent with previous findings of the literature on the private returns to investments in ICTs. Our variable of interest, industry-wide adoption of the Internet as a means of communication, is positive significant and changes only modestly as additional factors, including the proxy for firms' own investment in ICTs, are added.

Panel B of Table 3 shows similarly positive significant effects on average firms' investment in equipment (columns 1 and 2). We also identify positive effects on firms' ownership of quality certificates (columns 3 and 4) and patents (columns 5 and 6). These effects hold also if the same comprehensive set of firm controls applied for Panel A of Table 3 is included. Overall, our results provide evidence that industries' adoption of the Internet facilitates positive spillover effects on firms' productivity and innovation performance, confirming the first empirical hypothesis.

As for the magnitude of estimated effects, all else equal, our findings indicate that a one standard deviation rise in the intensity of a firm's industries' use of the Internet would improve its labor productivity by an amount equivalent to productivity increasing from the $50^{\text {th }}$ to the $54^{\text {th }}$ percentile of the distribution and from the $50^{\text {th }}$ to the $55^{\text {th }}$ percentile of equipment investment. Impacts 
on firms' ownership of quality certificates and patents are modest. An increase by one standard deviation would, all else equal, lead to an increase in formal intellectual property rights' ownership of $3 \%$ and $5 \%$ respectively.

\subsection{Robustness Tests}

This section presents robustness tests of our results. Findings for labor productivity are reported in Table 4. First, we test whether our results are robust to including additional controls. Results reported in column (1) add other industry characteristics as these might be correlated with industries' Internet adoption. In order to ensure our variable of interest does not pick up the effects of other industry characteristics, we obtain for each of the firm-level variables the corresponding contextual equivalent. That is, we include measures for country industries' average employment, their age, foreign ownership status, the volume of exporter activities, an indicator of public ownership, the share of multi-plant establishments, the average of years of managers' experience and an indicator of credit access for each specific year. Results, reported in column (1) of Table 4, confirm our evidence is robust to the inclusion of such measures. Unreported tests show our results also hold if we include firms' past productivity performance as a control to account for a variety of possible omitted factors. ${ }^{12}$ We also check whether controlling for firms' location in different agglomerations (column 2) modifies our findings by adding location fixed effects to our specification. We do not find this to be the case. Our results are not driven by differences regarding where firms are located.

Second, we check if our evidence is consistent with the findings of the literature that has documented positive effects of firms' own investments in ICTs on their performance. In order to avoid endogeneity, we adopt the strategy used in Fisman and Svensson (2007) and instrument firms' use of the Internet by the industry average. Our results, reported in column (3) of Table 4, document positive significant effects and correspond to positive findings identified by the previous literature on firm returns to private investments in ICTs.

Third, we check whether our results are different for firms in the manufacturing and services sectors. As shown in column (4), we find positive significant effects for both types of firms but larger returns for services firms. This may be related to the fact that for the services firms the transfer of intangible knowledge is even more critical than for manufacturing firms (where tangible assets continue to matter). Thus, they may gain more from wider access to knowledge.

Fourth, our main results focus on spillover effects within the firm's industry, as product markets provide most of the relevant knowledge for firms' innovation and productivity performance. As part of our robustness, we test whether we find similar results for differently defined sources of knowledge spillovers for firms. We obtain three alternative more restrictive measures of the relevant industry's adoption of the Internet by country-year. The first measure obtains separate measures of industries' adoption of the Internet for smaller and large firms. Smaller firms may have more to gain from other

\footnotetext{
${ }^{12}$ All unreported results are available from the authors upon request.
} 
firms of similar size as processes adopted by large firms may be out of reach for them. By contrast, for large firms the practices adopted by smaller entities may be irrelevant. The second measure, which was also used in Fisman and Svensson (2007), obtains separate measures of industries' adoption of the Internet for different types of locations. That is, it associates to firm $i$ the adoption of the Internet by those of industry $j$ located in a similarly sized location. The measure does not indicate whether firms are geographically close. The rationale for computing this type of measure is that firms in rural areas with very few inhabitants may have more to gain from the practices of other firms located in similar types of locations. ${ }^{13}$ The third measure focuses on explicitly geographic proximity by obtaining industry adoption rates separately for firms co-located in the capital city or elsewhere. This indicator reflects the hypothesis that the Internet may only benefit in a complementary way with co-location. Unfortunately, the only geographic information we have is about whether firms are located in the capital city. It is, therefore, a rather crude measure of geographic proximity. Results reported in columns (5), (6) and (7) of Table 4 are positive significant and larger compared to our baseline results of Table 3. Unreported results, using a measure of Internet adoption for country-location-year level (as in Arnold et al., 2008, and Dollar et al., 2006), are also positive significant.

Finally, we test whether access to higher exposure to technology will lead to even larger returns. We do so by interacting our variable of interest with whether these industries use imported technologies intensively or not. This follows the above-mentioned literature on the large knowledge benefits from foreign knowledge sources. We find effectively that spillover returns from the Internet are larger where the exposure to technology is larger. The difference in returns is positive significant.

Robustness tests for our measures of innovation performance are shown in Appendix Table 3. As shown in Panel A, we find robustness tests largely confirm findings regarding firms' investments in equipment. With regards to effects across manufacturing and services firms we do not find significant differences (Column 4). We also do not find impacts to be different with regards to the exposure to technology. With regards to quality certificates and patents, Panels B and C of Appendix Table 3 show our overall evidence to be less robust than that on productivity and equipment investments. We find higher quality knowledge leads to larger spillover effects (columns 8 and 7 of Panel B and C, respectively). With regards to quality certificates, manufacturing firms benefit more. We cannot report similar tests for patents, for which we have mainly information on patenting firms.

\subsection{Testing for Heterogeneous Impacts of the Internet across Firms}

We test our second hypothesis regarding whether gains from industry Internet adoption are heterogeneous. We explore in particular differences in impacts across a) exporters versus nonexporters, $b$ ) firms located in larger and smaller agglomerations, $c$ ) single- and multi-product firms, and $d$ ) smaller and larger firms. We also test whether $e$ ) informal businesses benefited from their industries' adoption of the Internet.

\footnotetext{
${ }^{13}$ Unreported results for a measure of Internet adoption by location-type, firm size, sector, country and year are also positive significant. Aterido et al. (2007) apply this approach in their analysis.
} 
Panel A of Table 5 reports results for impacts on labor productivity. We find that there is more to be gained for non-exporters (Column 1 of Panel A of Table 5). Unreported results indicate that national firms also benefited more than foreign-owned firms. Column (2) of Panel A of Table 5 shows results of equation (3) by agglomeration type. We split into those located in countries' capitals or in cities of more than 1 million inhabitants and those located in smaller agglomerations. Controlling for possible effects of location, we find statistically significant stronger impacts on labor productivity for firms in small agglomerations. Column (3) of Panel A of Table 5 shows that single-plant firms benefit more compared to multi-plant firms. Finally, with regards to differently sized firms, as reported in Column (4) of Panel A of Table 5, we do not find evidence of heterogeneous effects when it comes to labor productivity.

The evidence for innovation indicators also points to differential effects, but is more mixed. We identify weaker effects on exporters, as shown in columns (1), (5) and (9) of Panel B of Table 5. As for location, while we find that firms in remote locations to have larger returns for all innovation indicators, the coefficient is only statistically significant for firms' ownership of quality certificates. Results are shown in columns (2), (6) and (10) of Panel B of Table 5. As reported in columns (3), (7) and (11) of Panel B of Table 5 we also find larger benefits for multi-plant firms when it comes to quality certificate and patent ownership but not for equipment investment levels. With regards to firm size differences, we find as reported in columns (4), (8) and (12) no significant effects, except for results on quality certificates.

Finally, column (1) of Table 6 shows that informal businesses also benefited from knowledge spillovers in terms of their sales gains. In the case of informal business we use the industry's use of cellphones as a proxy for the "digitization" of informal business sectors. The evidence is maintained if control variables - firm employment size, their age, their ownership of bank accounts and whether they had a loan - are added. ${ }^{14}$ What is more, columns (3) - (4) show industry cell phone use also had positive impacts on informal firms' machinery investments.

In conclusion, our evidence suggests that the Internet provides larger opportunities for firms facing fewer opportunities for tapping into alternative knowledge sources, particularly when it comes to their labor productivity and also to some extent for certain innovation efforts. This, however, does not hold for differently sized firms. We also identify effects for informal businesses, confirming previous case study evidence of wider benefits.

\subsection{Testing for the Effects of "Absorptive Capacities"}

We test our third hypothesis on the importance of firms' "absorptive" capacities for benefits from Internet-enabled knowledge spillovers. In order to test whether average firm effects identified so far hide highly differential benefits, we conduct quantile regressions of impacts on labor productivity. Results for equation (1), which are shown in Figure 3, indicate differences in the benefits from

\footnotetext{
${ }^{14}$ We select a different set of control variables due to the different nature of firms analysed and the different variables contained in the informal firm survey.
} 
industries' adoption of the Internet exist. Returns are quite low for firms with productivity below the $35^{\text {th }}$ percentile and increase steadily afterwards, leveling off for firms reaching the $70^{\text {th }}$ percentile. The finding lends support to the "absorptive" capacities hypothesis for firms to effectively benefit from the knowledge spillovers facilitated by the Internet. The least productive firms hardly reap positive returns from their industries' Internet adoption.

In addition, we test how impacts identified across firm characteristics change across the productivity distribution. With regards to exporter status, Figure 4 (a) shows highest differential returns for non-exporting firms arise at productivity levels above the median. While the gains for exporters rise only marginally across the productivity distribution, we find benefits for non-exporters remain fairly low, even for the most productive firms. In other words, the larger average impacts identified in our previous analysis are driven by much larger gains for the most productive nonexporters. There is hardly any difference in (low) benefits for the least productive firms.

Figure 4 (b) plots the coefficients of our variable of interest across firms' location in different agglomerations. Both groups of firms reap fewer gains at lower levels of the productivity distribution while gains are much larger for firms with productivity levels above the median. The gap between largest and smallest locations is largest for the firms with productivity around the median productivity range. Above the median productivity threshold there is a leveling off of benefits in that more productive firms do not gain additional benefits. This might be because for the most productive firms there are relatively fewer efficiency improvements to be had from stronger knowledge spillovers.

Moreover, Figure 4 (c) reports results for multi- and single-product firms. The evidence shows that the Internet provided limited returns to the least productive single- and multi-product firms. However, for the group of single-product firms the benefits rise particularly for firms with productivity above the median. By contrast, for multi-product firms the rise is modest only. As is the case of results for exporters and non-exporters, we find that the higher average gains reported in Table 5 are driven by the large returns for the most productive non-exporters.

Last, Table 7 shows quantile regression estimates, which include an interaction term for firm size differences. While aggregate results reported in Table 5 do not show differences in effects, quantile regression results indicate that there are differences across small and large firms. Larger firms have lower benefits than smaller ones among those beyond the median distribution of firms.

Finally, with respect to innovation indicators, we find, as shown in Table 8, that when splitting impacts for firms with past above- or below-median productivity or different performance quantiles, the returns are larger for those with higher productivity with respect to their equipment investments and quality certificates. We find no evidence of differences for patenting activities.

\section{Concluding Remarks}

This paper provides systematic evidence of the positive impact of industries' Internet use on firm performance for 50,013 firm observations, covering 117 countries for 2006-2011. These gains, 
which did not depend on firms' own ICT investments, provide support for public policies aimed at fostering industries' use of the Internet. We also find that the Internet provided larger benefits to firms located in smaller agglomerations, to single-plant establishments and to non-exporters. These firms commonly engage less in innovation and consequently Internet-enabled knowledge spillovers can serve the "democratization of innovation". That is the more so the case because positive effects also arise even in contexts where firms face financial constraints, frequent power outages, skills shortages, corruption or cumbersome labor regulations (Paunov and Rollo, 2014). Having more inclusive innovation processes is particularly critical in many emerging and developing countries, as in these economies often only a very small number of firms innovate (Paunov, 2013). However, we also find that only the more productive firms among those types of firms benefited more than others. This points to the continued importance of policies aimed at building firms' innovation capacities. Otherwise, the Internet will only play a limited role in supporting inclusive innovations. Finally, questions for future research arise, including how increasingly more sophisticated uses of the Internet influence potential spillovers and returns to firm performance. Adjusting firm surveys to take novel applications into account is critical for such research. 


\section{References}

Acs, Z. J., Audretsch, D. B., and M. P. Feldman(1994), R\&D spillovers and recipient firm size, The Review of Economics and Statistics, 76(2), 336-40.

Agrawal, A. and A. Goldfarb (2008), Restructuring Research: Communication Costs and the Democratization of University Innovation, The American Economic Review, 2008, 98:4, pp. 1578-1590.

Aterido, R., Hallward-Driemeier, M. and C. Pagés (2007), Investment Climate and Employment Growth; The Impact of Access to Finance, Corruption and Regulations Across Firms, IZA Working Paper No. 3138.

Bas, M. and C. Paunov (2014), The unequal effect of India's industrial liberalization on firms' decision to innovate: Do business conditions matter?, OECD, unpublished manuscript.

Aker, J. C. and I. M. Mbiti (2010), "Mobile Phones and Economic Development in Africa", Journal of Economic Perspectives, Vol. 24, pp. 207-232.

Almeida, R., and A. M. Fernandes (2008), “Openness and technological innovations in developing countries: evidence from firm-level surveys”, The Journal of Development Studies, Vol. 44/5, pp. 701-727.

Arnold, J. M., Mattoo A. and G. Narciso (2008),"'Services Inputs and Firm Productivity in SubSaharan Africa: Evidence from Firm-Level Data", Journal of African Economies, Vol. 17, pp. 578-599.

Arrow, K. J. (1962),"Economic Welfare and the Allocation of Resources for Invention," in R. Nelson, (ed.), The rate and direction of inventive activity, Princeton University Press, 1962, pp. 609- 626.

Arthur, W. B. (2007),’The structure of invention”, Research Policy, Vol. 36/2, pp. 274-287.

Audretsch, D. and M. Feldman (2004), "Knowledge Spillovers and the Geography of Innovation", Handbook of Regional and Urban Economics, Vol. 4, pp. 2713-2739.

Audretsch, D. and M. Feldman (1996), "R\&D spillovers and the geography of innovation and production", The American Economic Review, pp. 630-640.

Bartel, A., Ichniowski, C. and K. Shaw (2007), "How does information technology affect productivity? Plant-level comparisons of product innovation, process improvement, and worker skills", The Quarterly Journal of Economics, Vol. 122/4 , pp. 1721-1758.

Black, S. E. and L. M. Lynch (2004), "What's driving the new economy?: the benefits of workplace innovation", The Economic Journal, Vol. 114/493, pp. 97-116.

Black, S.and L. Lynch (2001), "How to Compete: The Impact of Work- place Practices and Information Technology on Productivity", The Review of Economics and Statistics, Vol. 83/3 ,pp. 434-445.

Bloom, N., Sadun, R., \& Van Reenen, J. (2012), “Americans Do IT Better: US Multinationals and the Productivity Miracle”, The American Economic Review, vol. 102(1), pages 167-201, February.

Bloom, N., Schankerman, M. and J. Van Reenen (2013), "Identifying Technology Spillovers and Product Market Rivalry”, Econometrica, Vol. 81/4, pp. 1347-1393.

Bresnahan, T.F., Brynjolfsson, E. and L. M. Hitt (2002), "Information Technology, Workplace Organization, and The Demand For Skilled Labor: Firm-Level Evidence", The Quarterly Journal of Economics, Vol. 117, pp. 339-376.

Bresnahan, T., Greenstein, S., Brownstone, D., and K. Flamm (1996), "Technical progress and coinvention in computing and in the uses of computers", Brookings Papers on Economic Activity. Microeconomics, pp. 1-83.

Brynjolfsson, E. and L. M. Hitt (2000), "Beyond computation: Information technology, organizational transformation and business performance", The Journal of Economic Perspectives, pp. 23-48.

Brynjolfsson, E., Hitt, L. M. and H. Kim (2011), "Strength in numbers: how does data-driven decision-making affect firm performance?", MIT, unpublished manuscript. 
Cairncross, F. (1997), The Death of Distance, Harvard University Press.

Commander, S., Harrison, R. and N. Menezes-Filho (2011), "ICT and Productivity in Developing Countries: New Firm-Level Evidence from Brazil and India", The Review of Economics and Statistics, Vol. 93, pp. 528-541.

Coad, A. and R. Rao (2008), "Innovation and firm growth in high-tech sectors: A quantile regression approach", Research Policy, Vol. 37/4, p. 633-648.

Coe, D. T. and E. Helpman (1995), "International R\&D spillovers“, European Economic Review, Vol. $39 / 5$, p. $859-887$.

Cohen, W. M. (2010). Fifty years of empirical studies of innovative activity and performance. Handbook of the Economics of Innovation, 1, 129-213.

Cohen, W. and D. Levinthal (1989), "Innovation and Learning: The Two Faces of R\&D”, Economic Journal, Vol. 99, pp. 569-596.

Collard-Wexler, A., Asker, J., and J. De Loecker (2011), Productivity volatility and the misallocation of resources in developing economies, National Bureau of Economic Research.

Conley, T. G. and C. R. Udry (2010), "Learning about a new technology: Pineapple in Ghana", The American Economic Review, pp. 35-69.

Dethier, J.-J., Hirn, M. and S. Straub (2011), "Explaining Enterprise Performance in Developing Countries with Business Climate Survey Data", World Bank Research Observer, Vol. 26, pp. 258-309.

Ding, W. W., Levin, S. G., Stephan, P. E. and A. E.Winkler (2010), "The impact of information technology on academic scientists' productivity and collaboration patterns", Management Science, Vol. 56/9, pp. 1439-1461.

Dollar, D., Hallward-Driemeier, M. and T. Mengistae (2006), "Investment climate and international integration“, World Development, Vol. 34, pp. 1498-1516.

Donner, J. (2004), "Microentrepreneurs and Mobiles: An Exploration of the Uses of Mobile Phones by Small Business Owners in Rwanda“, Information Technologies and International Development, Vol. 2, pp. 1-21.

Donner, J. (2006). The use of mobile phones by microentrepreneurs in Kigali, Rwanda: Changes to social and business networks. Information Technologies and International Development 3, 3-19.

Donner, J. and M. Escobari (2010). A review of evidence on mobile use by micro and small enterprises in Developing Countries. Journal of International Development 22, 641-658.

Duncombe, R. and R. Heeks (2002). Enterprise across the digital divide: information systems and rural microenterprise in Botswana, Journal of International Development, Vol. 14, 61-74.

ECLAC (2011), ICT in Latin America, United Nations, Santiago, Chile.

Esselaar, S., Stork, C., Ndiwalana, A. and M. Deen-Swarra, (2007), "ICT usage and its impact on profitability of SMEs in 13 African Countries", Information Technologies and International Development, Vol. 4, pp. 87-100.

Fagerberg, J. (1994), "Technology and international differences in growth rates", Journal of Economic Literature, pp. 1147-1175.

Fattouh, B., Scaramozzino, P., and L. Harris (2005), "Capital structure in South Korea: a quantile regression approach”, Journal of Development Economics, Vol. 76/1, pp. 231-250.

Fisman, R. and J. Svensson (2007), "Are corruption and taxation really harmful to growth? Firm level evidence", Journal of Development Economics, Vol. 83, pp. 63-75.

Forman, C., Goldfarb, A. and S. Greenstein (2014), "Information Technology and the Distribution of Inventive Activity", NBER Working Paper 20036.

Forman, C., and N. Van Zeebroeck (2012), "From wires to partners: How the Internet has fostered R\&D collaborations within firms", Management Science, Vol. 58/8, pp. 1549-1568.

Freeman, C. and L. Soete (eds.) (1997), "The economics of industrial innovation", Psychology Press. 
Friedman, T. L. (2005), "The world is flat: A brief history of the twenty-first century", Farrar, Straus and Giroux.

Girma, S. (2005), "Absorptive capacity and productivity spillovers from fdi: A threshold regression analysis", Oxford Bulletin of Economics and Statistics, Vol. 67/3, p. 281-306.

Görg, H., and D. Greenaway (2004), "Much ado about nothing? Do domestic firms really benefit from foreign direct investment?", The World Bank Research Observer, Vol. 19/2, pp. 171-197.

Grossman, G. M. and E. Helpman (1991), "Innovation and Growth in the World Economy", MIT Press, Cambridge.

Haskel, J. E., Pereira, S. C. andM.J. Slaughter(2007), "Does inward foreign direct investment boost the productivity of domestic firms?", The Review of Economics and Statistics, Vol. 89(3), pp. 482-496.

Hu, A. G., Jefferson, G. H. and Q. Jinchang (2005), "R\&D and technology transfer: firm-level evidence from Chinese industry", The Review of Economics and Statistics, Vol. 87/4, p. 780-786.

ITU (2014), 2014 Facts and Figures, accessed at: http://www.itu.int/en/ITUD/Statistics/Documents/facts/ICTFactsFigures2014-e.pdf

Javorcik, B. S. (2004), "Does foreign direct investment increase the productivity of domestic firms? In search of spillovers through backward linkages“, The American Economic Review, Vol. 94/3, p. 605-627.

Jensen, R. (2007), "The Digital Provide: Information (Technology), Market Performance, and Welfare in the South Indian Fisheries Sector", The Quarterly Journal of Economics, Vol. 122, pp. 879924.

Jorgenson, D.W. (2001), "Information Technology and the U.S. Economy", The American Economic Review, Vol. 91/1, pp. 1-32.

Jorgenson, D. W. and K. Vu (2005), "Information Technology and the World Economy", The Scandinavian Journal of Economics, Vol. 1074, pp. 631-650.

Kaushik, P. D. and N. Singh (2004), "Information technology and broad-based development: preliminary lessons from North India“", World Development, Vol. 32/4, pp. 591-607.

Keller, W. (2004), “International Technology Diffusion”, Journal of Economic Literature, Vol. 42, pp. $752-782$.

Koenker, R. and G. Bassett (1978), "Regression quantiles”, Econometrica: journal of the Econometric Society, pp. 33-50.

Kokko, A. (1994), "Technology, market characteristics, and spillovers", Journal of Development Economics, Vol. 43/2, pp. 279-293.

Kokko, A., Tansini, R. and M. Zejan (1996), "Local technological capability and productivity spillovers from FDI in the Uruguayan manufacturing sector", The Journal of Development Studies, Vol. 32/4, pp. 602-611.

Krugman, P. (1991), "Increasing Returns and Economic Geography", The Journal of Political Economy, Vol. 99/3, p. 483-499.

Leamer, E. E. and M. Storper (2001), The economic geography of the Internet age, NBER Working Paper No. 8450

Motohashi, K. (2008), "IT, enterprise reform, and productivity in Chinese manufacturing firms. Journal of Asian Economics, Vol. 19, pp. 325-333.

Muto, M. and T. Yamano (2009), "The impact of mobile phone coverage expansion on market participation: Panel data evidence from Uganda", World Development, Vol. 37/12, p. 1887-1896.

Moulton, B. R. (1990), "An illustration of a pitfall in estimating the effects of aggregate variables on micro units", The Review of Economics and Statistics, pp. 334-338.

Oliner, S. D. and D. E. Sichel, (2000), "The Resurgence of Growth in the Late 1990s: Is Information Technology the Story?", Journal of Economic Perspectives, Vol. 14, pp. 3-22. 
Paunov, C. (2014), "Democratizing Intellectual Property Systems: How Corruption Hinders Equal Opportunities for Firms", unpublished manuscript.

Paunov, C. (2013), "Innovation and Inclusive Development: A Discussion of the Main Policy Issues (No. 2013/1)", OECD Publishing.

Paunov, C and V. Rollo (2014), "Overcoming Obstacles: The Internet's Contribution to Firm Development", World Bank Economic Review, Papers \& Proceedings, forthcoming.

Romer, P. (1986), "Increasing Returns and Long- Run Growth." Journal of Political Economy, Vol. 94/5, pp. 1002-1037.

Schneider, F.,Buehn A. and C. E. Montenegro (2011), "Shadow Economies all over the World: New Estimates for 162 Countries from 1999 to 2007", Handbook on the Shadow Economy, pp. 9-77.

Şeker, M., (2012) "Importing, Exporting, and Innovation in Developing Countries", Review of International Economics, Vol. 20, pp. 299-314.

Spezia, V. (2011), "Are ICT Users More Innovative? An Analysis of ICT-Enabled Innovation in OECD Firms", OECD Journal: Economic Studies, pp. 99-119.

Stiroh, K. J. (2002), "Information Technology and the U.S. Productivity Revival: What Do the Industry Data Say?", American Economic Review, Vol. 92, pp. 1559-1576.

UNCTAD (2008), Measuring the impact of ICT use in business: The case of manufacturing in Thailand, New York and Geneva.

Von Hippel, E. (2005), Democratizing Innovation, MIT Press, Boston.

Yasar, M. and C. J. Morrison Paul (2007), "International linkages and productivity at the plant level: Foreign direct investment, exports, imports and licensing", Journal of International Economics, Vol. 71/2, pp. 373-388.

World Bank (2006), "Information and Communication for Development: Global Trends and Policies", Washington, DC. 


\section{Figures and Tables}

Figure 1: Share of firms communicating with clients and suppliers by e-mail in 2006-2011 (in percentages)

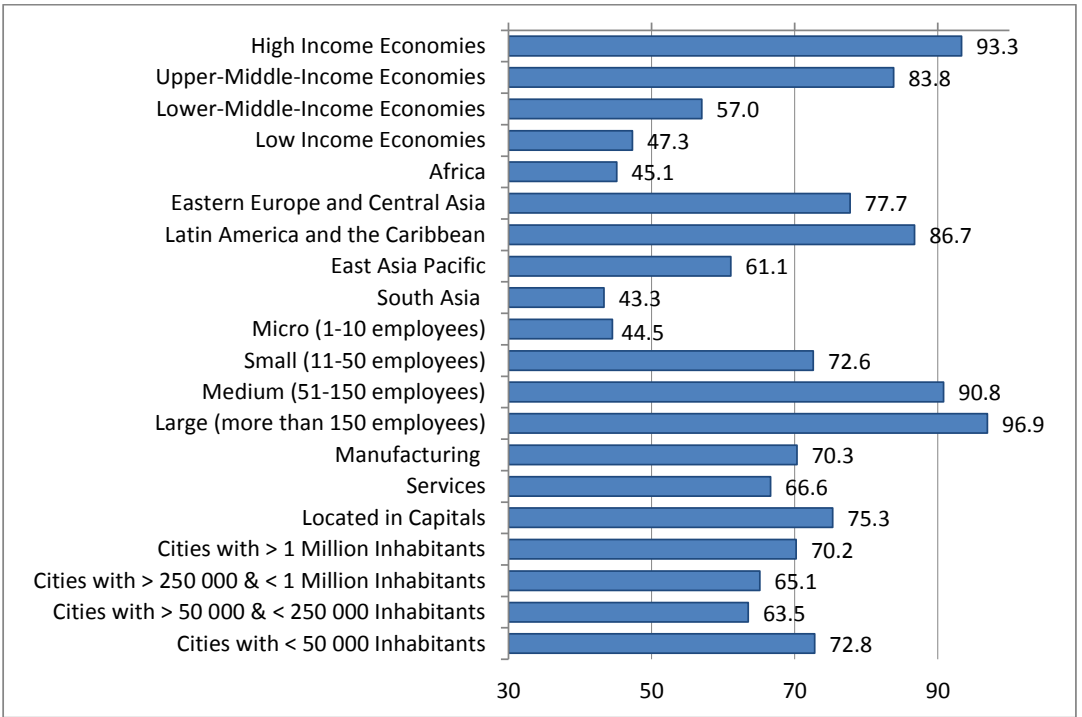

Note: Statistics provided are obtained for the 50,013 firms included in our baseline sample. See Table 2 and Appendix Table 1 for details regarding the sample. 
Figure 2: Percentiles of industries' adoption of the Internet across countries

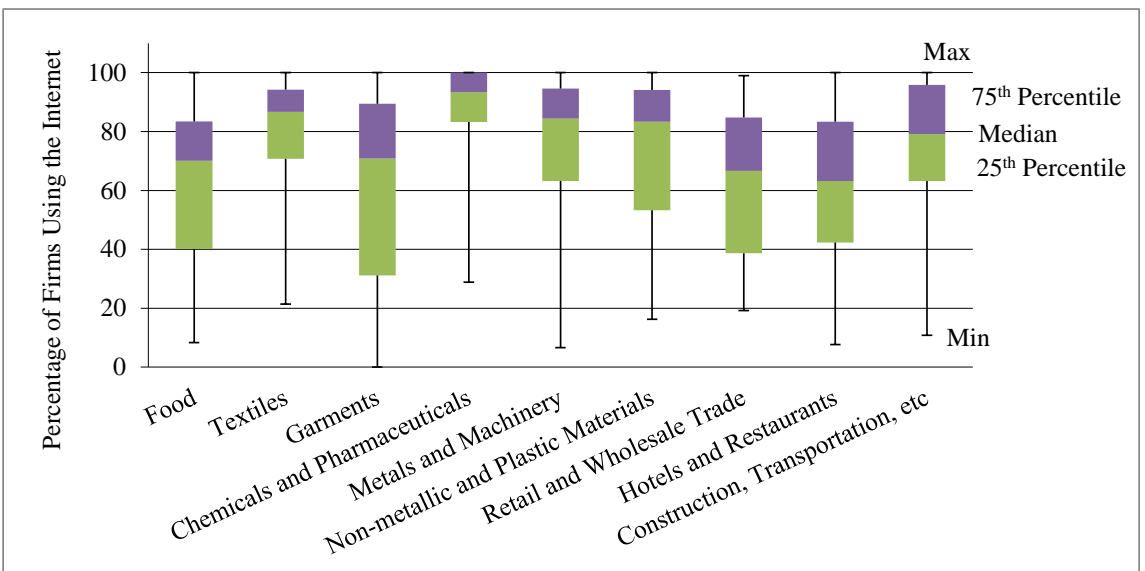

Note: The deciles for different industries are computed based on the following number of country observations on the share of firms using the Internet to communicate by email with clients and users: 110 for food, 71 for garments, 50 for textiles, 48 for chemicals and pharmaceuticals, 68 for metals and machinery, 64 for non-metallic and plastic materials, 123 for retail and wholesale trade and 74 for hotels and restaurants. Statistics provided are obtained for the 50,013 firms included in our baseline sample. See Table 2 and Appendix Table 1 for details regarding the sample. 
Figure 3: Estimated Coefficients of Quantile Regressions of Labor Productivity

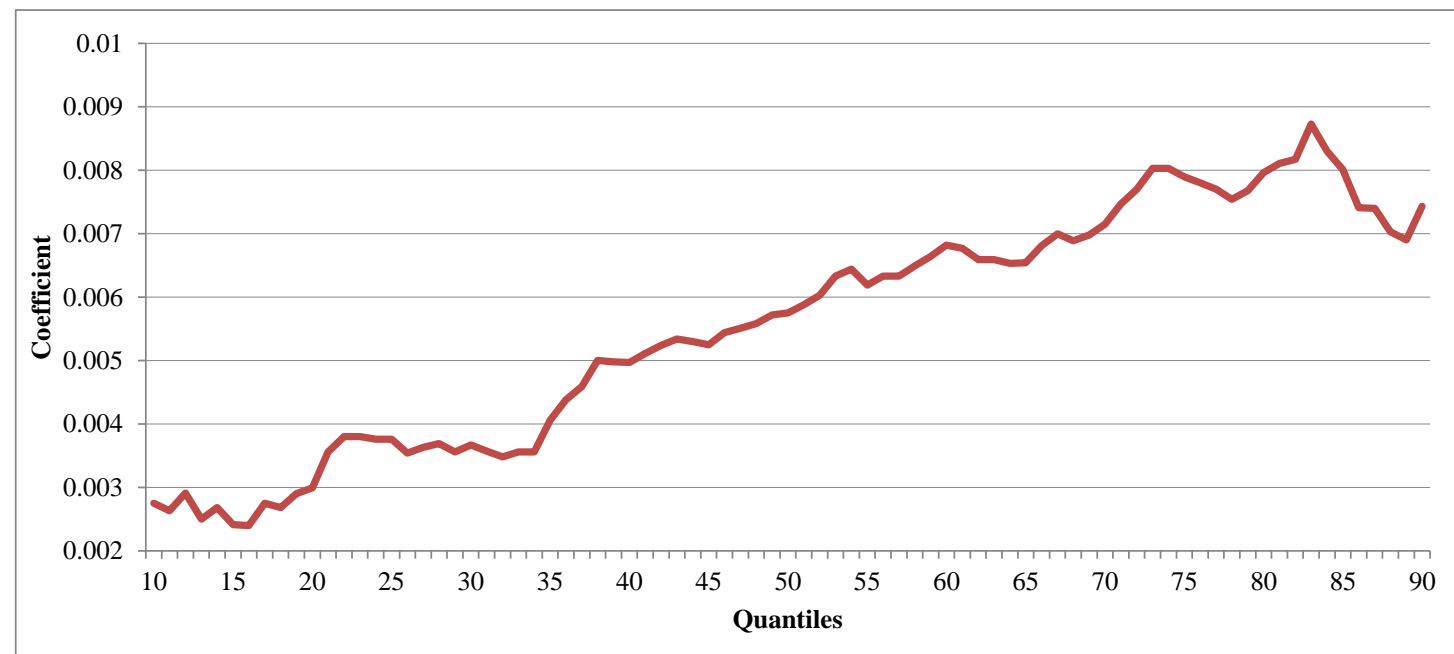

Note: The figure plots coefficients from quantile regressions of the impact of the share of firms using email on labor productivity for the $10^{\text {th }}$ to the $90^{\text {th }}$ quantile of the distribution. 
Figure 4: Estimated Coefficients of Quantile Regressions of Firms' Use of the Internet

(a) By Exporter Status

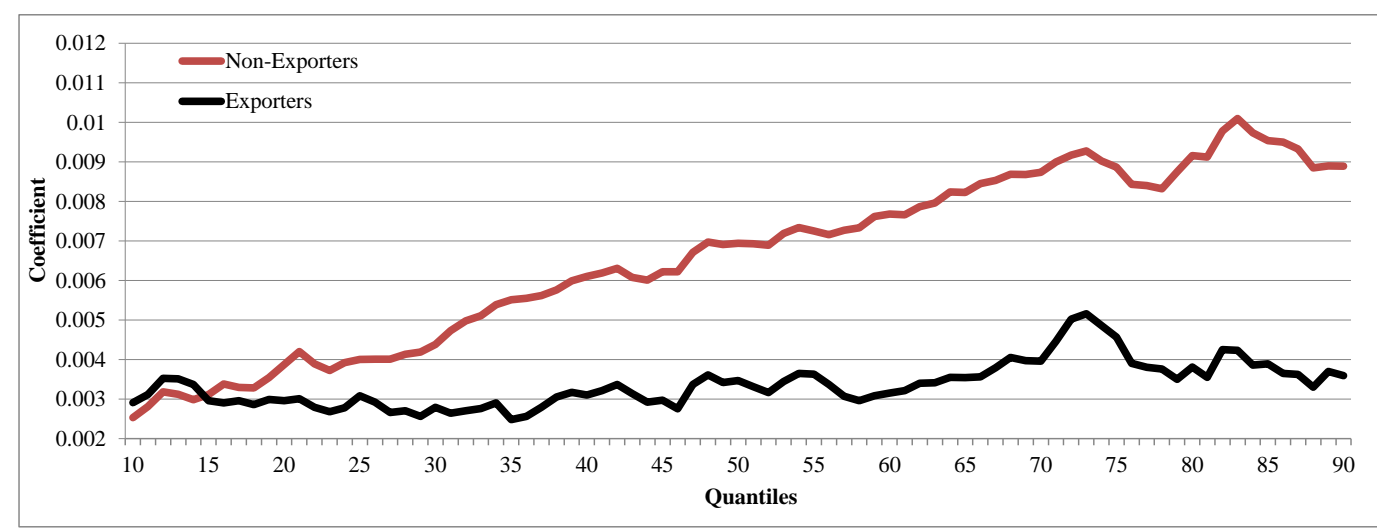

(b) By Agglomeration Type

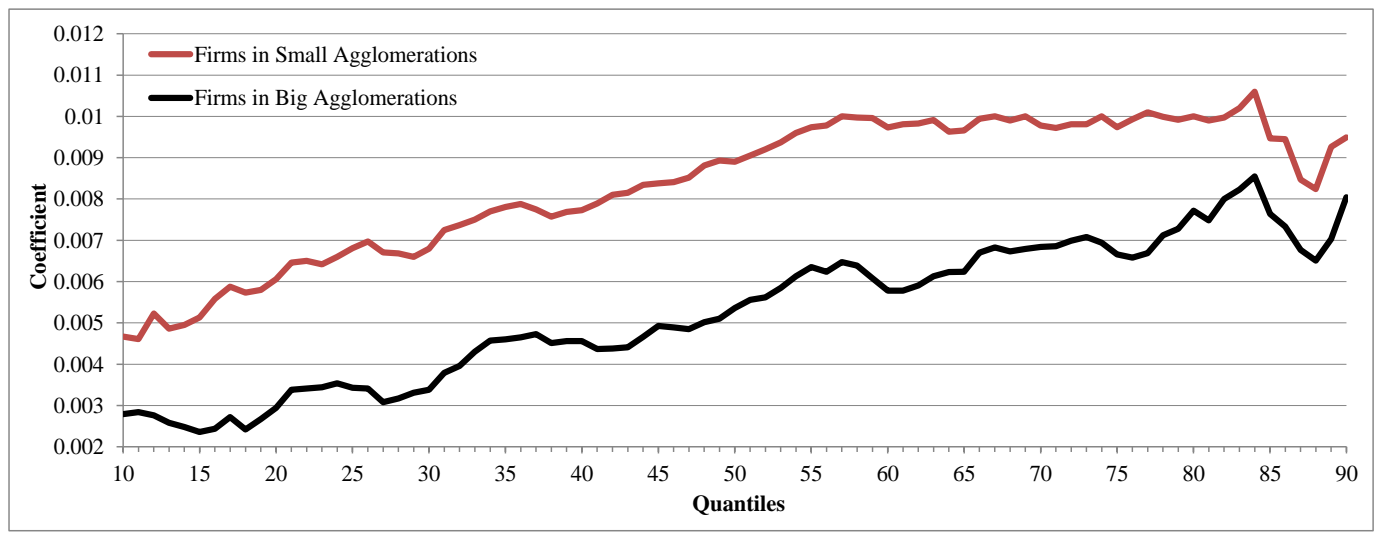

(c) By Single- and Multi-Plant Firms

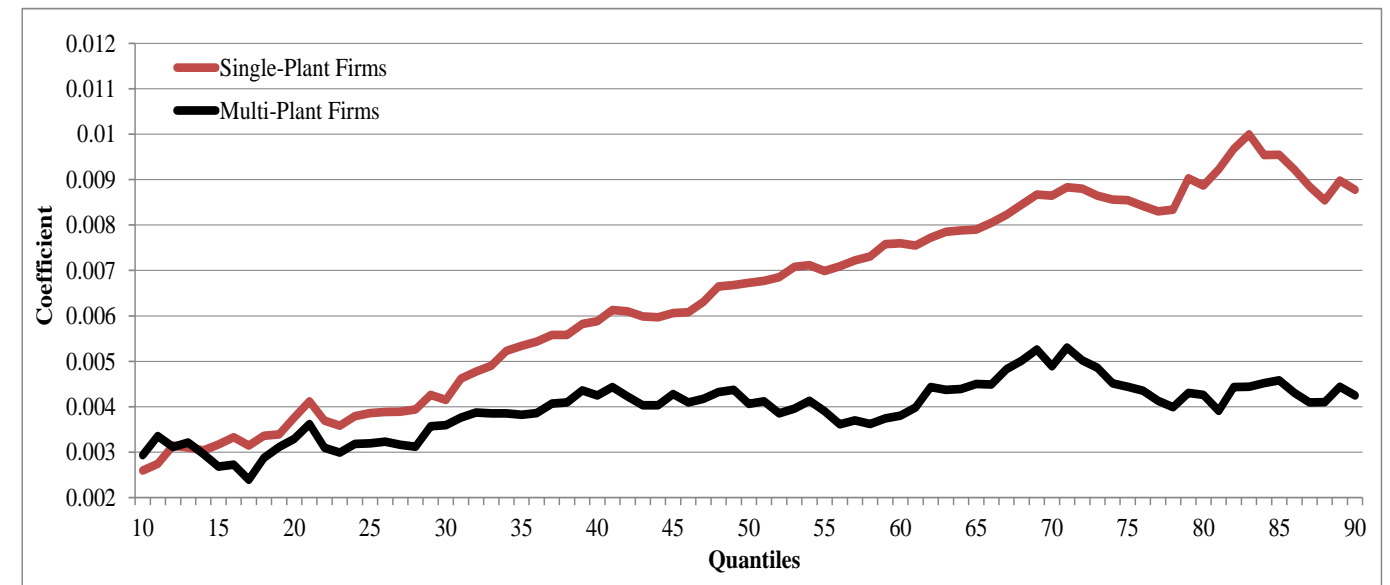

Note: The figures plots coefficients from quantile regressions of the impact of industry in big and small agglomerations as in column (3) of Panel A of Table 5 on labor productivity for the $10^{\text {th }}$ to the $90^{\text {th }}$ quantile of the distribution. 
Table 1: Statistics on Technology Use of the Informal Sector in 2009-2010

\begin{tabular}{|c|c|c|c|c|c|c|}
\hline & \multicolumn{2}{|c|}{ Overall } & \multicolumn{2}{|c|}{ AFR } & \multicolumn{2}{|c|}{ LAC } \\
\hline & Firm Nbr. & cent & Firm Nbr. & Percent & Firm Nbr. & Percent \\
\hline \multicolumn{7}{|c|}{ Use of cell-phone } \\
\hline No & 1026 & 40.7 & 295 & 23.8 & 674 & $\overline{58.0}$ \\
\hline Yes & 1495 & 59.3 & 943 & 76.2 & 489 & 42.1 \\
\hline \multicolumn{7}{|c|}{ Use of electricity } \\
\hline No & 553 & 24.9 & 369 & 29.7 & 178 & 20.7 \\
\hline Yes & 1668 & 75.1 & 873 & 70.3 & 681 & 79.3 \\
\hline \multicolumn{7}{|c|}{ Experienced power outages } \\
\hline No & 765 & 46.1 & 275 & 31.8 & 489 & $\overline{72.0}$ \\
\hline Yes & 894 & 53.9 & 591 & 68.2 & 190 & 28.0 \\
\hline
\end{tabular}

Note: Information is based on firm observations for 14 countries: Angola, Argentina, Botswana, Burkina Faso, Cameroon, Cape Verde, Democratic Republic of Congo, Ivory Coast, Guatemala, Madagascar, Mali, Mauritius, Nepal and Peru. 
Table 2: Descriptive Statistics

\begin{tabular}{|c|c|c|}
\hline & $\begin{array}{c}\text { Number of } \\
\text { Observations }\end{array}$ & $\begin{array}{c}\text { Share in } \\
\text { Total }\end{array}$ \\
\hline \multicolumn{3}{|l|}{ Region } \\
\hline Africa & 13,741 & $27.5 \%$ \\
\hline Eastern Europe and Central Asia & 9,968 & $19.9 \%$ \\
\hline Latin America and the Caribbean & 19,772 & $39.5 \%$ \\
\hline Middle East & 1,007 & $2.0 \%$ \\
\hline East Asia Pacific & 3,677 & $7.4 \%$ \\
\hline South Asia & 1,848 & $3.7 \%$ \\
\hline \multicolumn{3}{|l|}{ Industry } \\
\hline Food & 6,326 & $12.7 \%$ \\
\hline Garments & 3,987 & $8.0 \%$ \\
\hline Textiles and Leather & 2,567 & $5.1 \%$ \\
\hline Wood and Furniture & 689 & $1.4 \%$ \\
\hline Non-metallic and Plastic Materials & 2,337 & $4.7 \%$ \\
\hline Metals, Machinery and Electronics & 3,738 & $7.5 \%$ \\
\hline Chemicals and Pharmaceuticals & 2,387 & $4.8 \%$ \\
\hline Other Manufacturing Activities & 6,921 & $13.8 \%$ \\
\hline Total Manufacturing & 28,952 & $57.9 \%$ \\
\hline \multicolumn{3}{|l|}{ Services (incl. Construction) } \\
\hline Hotels and Restaurants & 1,816 & $3.6 \%$ \\
\hline Retail and Wholesale Trade & 11,641 & $23.3 \%$ \\
\hline Construction and Transportation & 2,629 & $5.3 \%$ \\
\hline Other Services & 4,975 & $10.0 \%$ \\
\hline Total Services & 21,061 & $42.1 \%$ \\
\hline \multicolumn{3}{|l|}{ Size } \\
\hline Micro (1-10 employees) & 16,549 & $33.1 \%$ \\
\hline Small (11-50 employees) & 20,022 & $40.0 \%$ \\
\hline Medium (51-150 employees) & 7,772 & $15.5 \%$ \\
\hline Large (more than 150 employees) & 5,670 & $11.3 \%$ \\
\hline \multicolumn{3}{|l|}{ Year } \\
\hline 2006 & 12,280 & $24.6 \%$ \\
\hline 2007 & 8,261 & $16.5 \%$ \\
\hline 2008 & 2,382 & $4.8 \%$ \\
\hline 2009 & 14,057 & $28.1 \%$ \\
\hline 2010 & 11,182 & $22.4 \%$ \\
\hline 2011 & 1,851 & $3.7 \%$ \\
\hline \multicolumn{3}{|l|}{ Income Level } \\
\hline High Income & 2,627 & $5.3 \%$ \\
\hline Upper-middle Income & 21,126 & $42.2 \%$ \\
\hline Lower-middle Income & 17,925 & $35.8 \%$ \\
\hline Low Income & 8,335 & $16.7 \%$ \\
\hline Full Sample & 50,013 & \\
\hline
\end{tabular}


Table 3: Baseline Results

Panel A: Labor Productivity

\begin{tabular}{|c|c|c|c|c|c|c|}
\hline & \multicolumn{6}{|c|}{ Dependent Variable: Labor Productivity } \\
\hline & (1) & (2) & (3) & (4) & (5) & (6) \\
\hline Industry Internet Use & $\begin{array}{c}0.010^{* * * *} \\
(0.001)\end{array}$ & $\begin{array}{c}0.008^{* * * *} \\
(0.001)\end{array}$ & $\begin{array}{c}0.008 * * * \\
(0.001)\end{array}$ & $\begin{array}{c}0.007 * * * * \\
(0.001)\end{array}$ & $\begin{array}{c}0.007^{* * * *} \\
(0.001)\end{array}$ & $\begin{array}{c}0.006^{* * * *} \\
(0.001)\end{array}$ \\
\hline \multicolumn{7}{|l|}{ Firm-Level Controls } \\
\hline Employment & & $\begin{array}{c}0.151^{* * * *} \\
(0.010)\end{array}$ & $\begin{array}{c}0.132 * * * \\
(0.010)\end{array}$ & $\begin{array}{c}0.082^{* * * * *} \\
(0.010)\end{array}$ & $\begin{array}{c}0.058^{* * * *} \\
(0.010)\end{array}$ & $\begin{array}{l}0.023^{* *} \\
(0.010)\end{array}$ \\
\hline Age & & $\begin{array}{c}0.083^{* * * *} \\
(0.011)\end{array}$ & $\begin{array}{c}0.078 * * * \\
(0.011)\end{array}$ & $\begin{array}{c}0.087 * * * \\
(0.011)\end{array}$ & $\begin{array}{c}0.078^{* * * *} \\
(0.011)\end{array}$ & $\begin{array}{c}0.075^{\text {**** }} \\
(0.011)\end{array}$ \\
\hline Public Ownership & & & $\begin{array}{l}-0.133^{*} \\
(0.073)\end{array}$ & $\begin{array}{c}-0.149 * * \\
(0.072)\end{array}$ & $\begin{array}{l}-0.121^{*} \\
(0.073)\end{array}$ & $\begin{array}{l}-0.136^{*} \\
(0.071)\end{array}$ \\
\hline Multi-Plant Firm & & & $\begin{array}{c}0.333 * * * \\
(0.022)\end{array}$ & $\begin{array}{c}0.280 * * * \\
(0.022)\end{array}$ & $\begin{array}{c}0.285^{* * * *} \\
(0.022)\end{array}$ & $\begin{array}{c}0.254^{* * * *} \\
(0.022)\end{array}$ \\
\hline Foreign Ownership & & & & $\begin{array}{c}0.443^{* * * * *} \\
(0.025)\end{array}$ & $\begin{array}{c}0.476^{* * * *} \\
(0.026)\end{array}$ & $\begin{array}{r}0.453^{\text {***** }} \\
(0.025)\end{array}$ \\
\hline Exporter Status & & & & $\begin{array}{c}0.258^{* * * *} \\
(0.022)\end{array}$ & $\begin{array}{c}0.241 * * * \\
(0.022)\end{array}$ & $\begin{array}{c}0.191 \text { **** } \\
(0.021)\end{array}$ \\
\hline Credit Access & & & & & $\begin{array}{c}0.302^{* * * *} \\
(0.016)\end{array}$ & $\begin{array}{c}0.279 \text { **** } \\
(0.016)\end{array}$ \\
\hline Managerial Expertise & & & & & $\begin{array}{c}0.026^{* *} \\
(0.011)\end{array}$ & $\begin{array}{c}0.027^{* *} \\
(0.011)\end{array}$ \\
\hline Website & & & & & & $\begin{array}{c}0.386^{* * * *} \\
(0.017)\end{array}$ \\
\hline Industry Fixed Effects & Yes & Yes & Yes & Yes & Yes & Yes \\
\hline Country-Year Fixed Effects & Yes & Yes & Yes & Yes & Yes & Yes \\
\hline Observations & 56,169 & 55,121 & 52,839 & 52,146 & 50,107 & 50,013 \\
\hline$\underline{\mathrm{R}^{2}}$ & 0.79 & 0.80 & 0.80 & 0.81 & 0.81 & 0.81 \\
\hline
\end{tabular}

Panel B: Indicators of Innovation Performance

\begin{tabular}{|c|c|c|c|c|c|c|}
\hline & \multirow{2}{*}{\multicolumn{2}{|c|}{$\begin{array}{c}\text { Equipment Investment } \\
\text { OLS Regressions }\end{array}$}} & \multicolumn{2}{|c|}{ Quality Certificates } & \multicolumn{2}{|c|}{ Patents } \\
\hline & & & \multicolumn{4}{|c|}{ Logistic Regressions } \\
\hline & (1) & (2) & (3) & (4) & (5) & (6) \\
\hline \multirow[t]{3}{*}{ Industry Internet Use } & $0.016^{* * *}$ & $0.009^{* * * *}$ & $0.019 * * *$ & $0.005^{* *}$ & $0.018^{* * * *}$ & $0.012^{* *}$ \\
\hline & & & {$[0.003]$} & {$[0.001]$} & {$[0.004]$} & {$[0.002]$} \\
\hline & $(0.003)$ & $(0.003)$ & $(0.002)$ & $(0.002)$ & $(0.004)$ & $(0.005)$ \\
\hline Firm-Level Controls & No & Yes & No & Yes & No & Yes \\
\hline Industry Fixed Effects & Yes & Yes & Yes & Yes & Yes & Yes \\
\hline Country-Year Fixed Effects & Yes & Yes & Yes & Yes & Yes & Yes \\
\hline Observations & 36,501 & 33,080 & 61,965 & 54,586 & 9,879 & 9,061 \\
\hline $\mathrm{R}^{2}$ & 0.44 & 0.45 & & & & \\
\hline Pseudo $\mathrm{R}^{2}$ & & & 0.09 & 0.25 & 0.13 & 0.19 \\
\hline
\end{tabular}

Note: Panel A reports results from ordinary least squares regressions. Robust standard errors clustered at country-industryyear level are shown in parentheses. For logistic regressions, marginal effects are reported in brackets. Firm-level controls are the same as those of column (5) of Panel A of Table 3. ***, ** and * indicate significance at 1\%, 5\% and $10 \%$ confidence levels, respectively. 
Table 4: Robustness

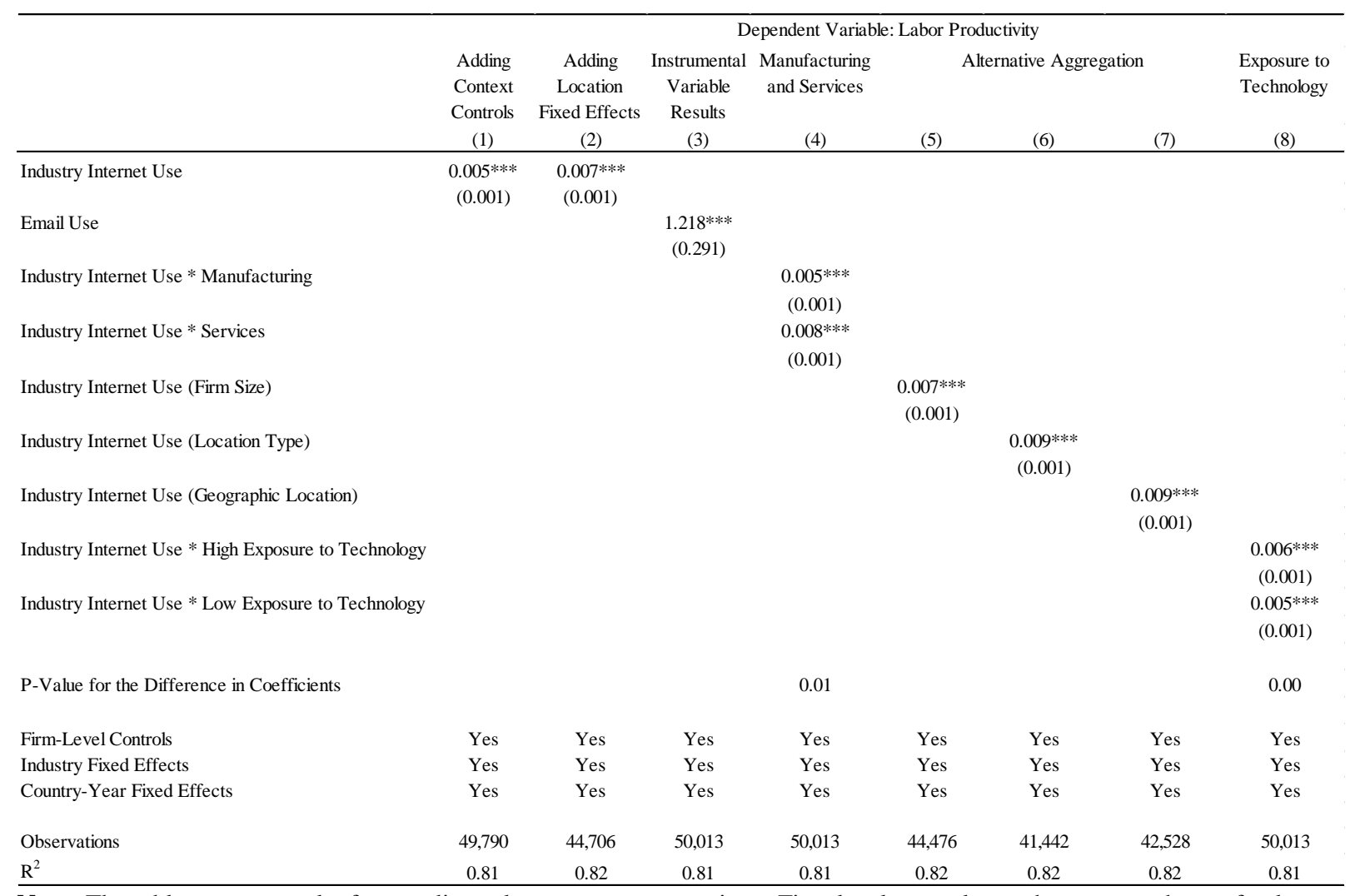

Note: The table reports results from ordinary least squares regressions. Firm-level controls are the same as those of column (5) of Panel A of Table 3. Robust standard errors clustered at country-industry-year level are shown in parentheses. ***, ** and $*$ indicate significance at $1 \%, 5 \%$ and $10 \%$ confidence levels, respectively. 


\section{Table 5: Firm Characteristics}

Panel A: Labor Productivity

\begin{tabular}{|c|c|c|c|c|}
\hline & \multicolumn{4}{|c|}{ Dependent Variable: Labor Productivity } \\
\hline & $\begin{array}{c}\text { Exporters } \\
\text { (1) }\end{array}$ & $\begin{array}{c}\text { Firm } \\
\text { Location } \\
(2)\end{array}$ & $\begin{array}{c}\text { Multi-Plant } \\
\text { Firms } \\
\text { (3) }\end{array}$ & $\begin{array}{c}\text { Firm Size } \\
\text { (4) }\end{array}$ \\
\hline Industry Internet Use * Exporters & $\begin{array}{l}0.003^{*} \\
(0.002)\end{array}$ & & & \\
\hline Industry Internet Use $*$ Non-Exporters & $\begin{array}{l}0.006^{* * * *} \\
(0.001)\end{array}$ & & & \\
\hline Industry Internet Use * Big Agglomeration & & $\begin{array}{c}0.005 * * * \\
(0.001)\end{array}$ & & \\
\hline Industry Internet Use * Small Agglomeration & & $\begin{array}{c}0.008^{* * * *} \\
(0.001)\end{array}$ & & \\
\hline Industry Internet Use * Multi-Plant Firms & & & $\begin{array}{l}0.004 * * \\
(0.002)\end{array}$ & \\
\hline Industry Internet Use * Single-Plant Firms & & & $\begin{array}{l}0.006^{* * * *} \\
(0.001)\end{array}$ & \\
\hline Industry Internet Use * Bigger Firms & & & & $\begin{array}{r}0.006^{* * * *} \\
(0.001)\end{array}$ \\
\hline Industry Internet Use * Small Firms & & & & $\begin{array}{c}0.006^{* * * *} \\
(0.001)\end{array}$ \\
\hline Firm Controls & Yes & Yes & Yes & Yes \\
\hline $\begin{array}{l}\text { Industry Fixed Effects } \\
\text { Country-Year Fixed Effects }\end{array}$ & $\begin{array}{l}\text { Yes } \\
\text { Yes }\end{array}$ & $\begin{array}{l}\text { Yes } \\
\text { Yes }\end{array}$ & $\begin{array}{l}\text { Yes } \\
\text { Yes }\end{array}$ & $\begin{array}{l}\text { Yes } \\
\text { Yes }\end{array}$ \\
\hline P-Value of the Difference in Coefficients & 0.00 & 0.01 & 0.04 & 0.45 \\
\hline Observations & 50,013 & 44,706 & 51,521 & 50,013 \\
\hline $\mathrm{R}^{2}$ & 0.81 & 0.82 & 0.81 & 0.81 \\
\hline
\end{tabular}

Note: The tables reports results from ordinary least squares regressions. Firm-level controls are the same as those of column (5) of Panel A of Table 3. Robust standard errors clustered at country-industry-year level are shown in parentheses. ***, ** and $*$ indicate significance at $1 \%, 5 \%$ and $10 \%$ confidence levels, respectively. 
Panel B: Firm Characteristics and Benefits from the Internet: Innovation Indicators

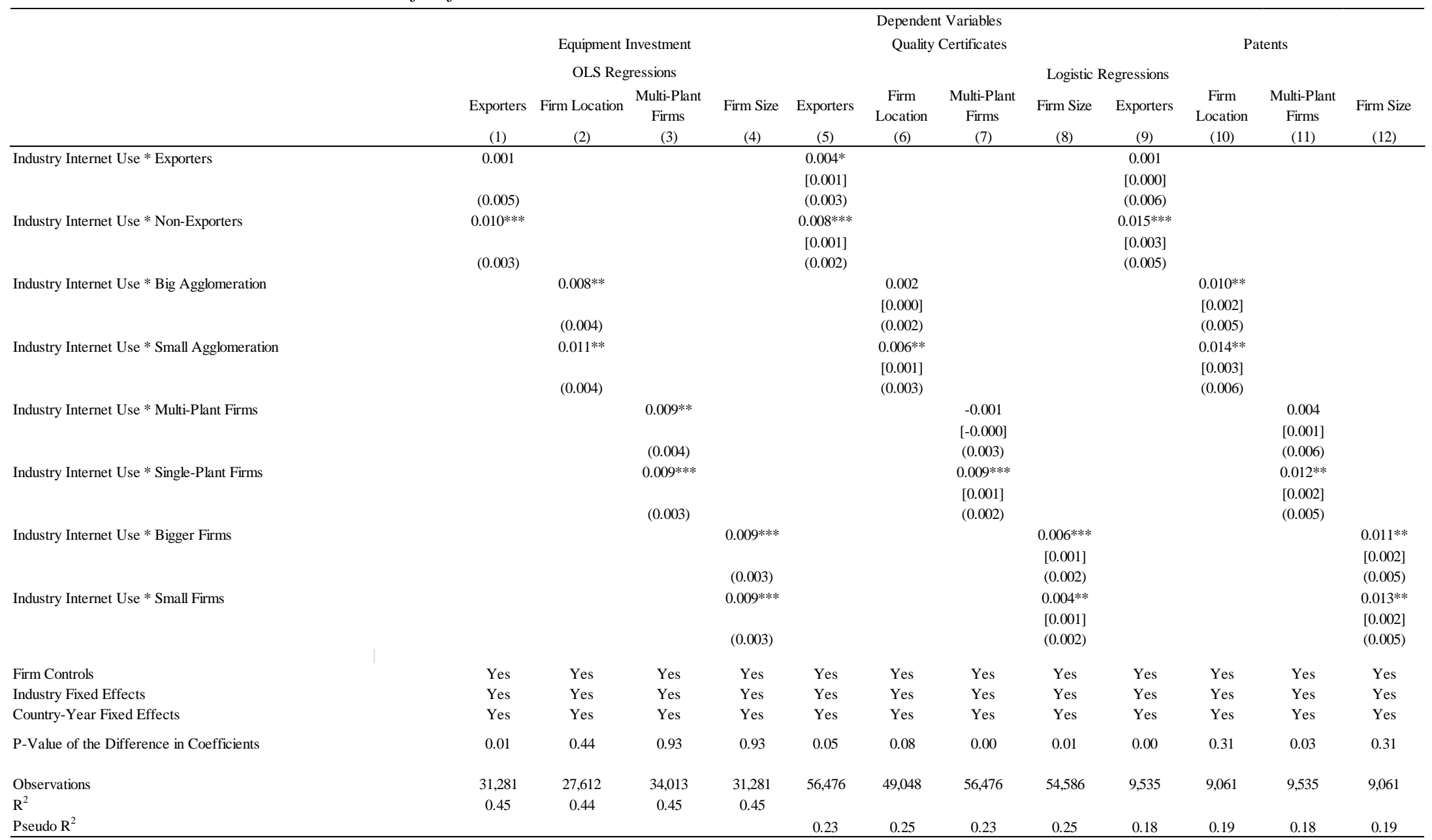

Note: Firm-level controls are the same as those of column (5) of Panel A of Table 3. Robust standard errors clustered at country-industry-year level are shown in parentheses. For logistic regressions, marginal effects are reported in brackets. $* * *, * *$ and $*$ indicate significance at $1 \%, 5 \%$ and $10 \%$ confidence levels, respectively. 
Table 6: Informal Businesses

\begin{tabular}{lcccc}
\hline & \multicolumn{5}{c}{ Dependent Variables: } \\
& $(1)$ & $(2)$ & $(3)$ & $(4)$ \\
\hline Industry Cell Phone Use & $0.010^{* *}$ & $0.011^{* *}$ & $0.017^{* *}$ & $0.016^{*}$ \\
& $(0.003)$ & $(0.003)$ & $(0.009)$ & $(0.009)$ \\
& & & & \\
Firm Controls & No & Yes & No & Yes \\
Industry Fixed Effects & Yes & Yes & Yes & Yes \\
Country-Year Fixed Effects & Yes & Yes & Yes & Yes \\
& & & & \\
Observations & 1,406 & 1,207 & 1,430 & 1,219 \\
$\mathrm{R}^{2}$ & 0.80 & 0.83 & 0.09 & 0.14 \\
\hline
\end{tabular}

Note: The table reports results from ordinary least squares regressions. Firm controls include employment size, their age, their ownership of bank accounts and whether they had a loan. Robust standard errors clustered at country-sector-year level are shown in parentheses. $* * * * *$ and $*$ indicate significance at $1 \%, 5 \%$ and $10 \%$ confidence levels, respectively. 
Table 7: Differential Impacts of Size across the Productivity Distribution

\begin{tabular}{|c|c|c|c|c|c|c|c|c|c|}
\hline & \multicolumn{9}{|c|}{$\begin{array}{c}\text { Dependent Variable: Labor Productivity } \\
\text { Quantile Regression }\end{array}$} \\
\hline & $\begin{array}{l}\text { Q1 } \\
(1)\end{array}$ & $\begin{array}{l}\text { Q2 } \\
(2)\end{array}$ & $\begin{array}{l}\text { Q3 } \\
(3)\end{array}$ & $\begin{array}{l}\text { Q4 } \\
(4)\end{array}$ & $\begin{array}{l}\text { Q5 } \\
(5)\end{array}$ & $\begin{array}{l}\text { Q6 } \\
(6)\end{array}$ & $\begin{array}{l}\text { Q7 } \\
(7)\end{array}$ & $\begin{array}{l}\text { Q8 } \\
(8)\end{array}$ & $\begin{array}{l}\text { Q9 } \\
(9)\end{array}$ \\
\hline Industry Internet Use $*$ Size & $\begin{array}{l}-0.000 \\
(0.000)\end{array}$ & $\begin{array}{c}-0.001^{* *} \\
(0.000)\end{array}$ & $\begin{array}{c}-0.002^{* * * *} \\
(0.000)\end{array}$ & $\begin{array}{c}-0.002^{* * *} \\
(0.000)\end{array}$ & $\begin{array}{c}-0.002^{* * *} \\
(0.000)\end{array}$ & $\begin{array}{c}-0.003^{* * *} * \\
(0.000)\end{array}$ & $\begin{array}{c}-0.003^{* * * *} \\
(0.000)\end{array}$ & $\begin{array}{c}-0.003^{* * *} \\
(0.001)\end{array}$ & $\begin{array}{c}-0.003^{* * *} \\
(0.001)\end{array}$ \\
\hline Industry Internet Use & $\begin{array}{c}0.003 \\
(0.002)\end{array}$ & $\begin{array}{c}0.006^{* * * *} \\
(0.002)\end{array}$ & $\begin{array}{c}0.009^{* * * *} \\
(0.002)\end{array}$ & $\begin{array}{c}0.011^{* * *} \\
(0.002)\end{array}$ & $\begin{array}{c}0.012 * * * \\
(0.002)\end{array}$ & $\begin{array}{c}0.014 * * * \\
(0.002)\end{array}$ & $\begin{array}{c}0.015^{* * * *} \\
(0.002)\end{array}$ & $\begin{array}{c}0.015^{* * *} \\
(0.002)\end{array}$ & $\begin{array}{c}0.016^{* * * *} \\
(0.003)\end{array}$ \\
\hline Firm-Level Controls & Yes & Yes & Yes & Yes & Yes & Yes & Yes & Yes & Yes \\
\hline Industry Fixed Effects & Yes & Yes & Yes & Yes & Yes & Yes & Yes & Yes & Yes \\
\hline Country-Year Fixed Effects & Yes & Yes & Yes & Yes & Yes & Yes & Yes & Yes & Yes \\
\hline Observations & 50,013 & 50,013 & 50,013 & 50,013 & 50,013 & 50,013 & 50,013 & 50,013 & 50,013 \\
\hline
\end{tabular}

Note: Firm-level controls are the same as those of column (5) of Panel A of Table 3. Robust standard errors clustered at country-sector-year level are shown in parentheses. $* * *, * *$ and $*$ indicate significance at $1 \%, 5 \%$ and $10 \%$ confidence levels, respectively. 
Table 8: Impacts of Productivity Differences on Innovation Variables

\begin{tabular}{|c|c|c|c|c|c|c|}
\hline & \multirow{2}{*}{\multicolumn{2}{|c|}{$\begin{array}{c}\text { Equipment Investment } \\
\text { OLS Regressions }\end{array}$}} & \multicolumn{2}{|c|}{ Quality Certificates } & \multicolumn{2}{|c|}{ Patents } \\
\hline & & & \multicolumn{4}{|c|}{ Logistic Regressions } \\
\hline & (1) & (2) & (3) & (4) & $(5)$ & $(6)$ \\
\hline \multirow[t]{2}{*}{ Industry Internet Use * Below Median } & 0.005 & & $0.004 *$ & & $0.009^{*}$ & \\
\hline & $(0.003)$ & & $\begin{array}{l}{[0.000]} \\
(0.002)\end{array}$ & & $\begin{array}{l}{[0.002]} \\
(0.005)\end{array}$ & \\
\hline \multirow[t]{3}{*}{ Industry Internet Use * Above Median } & $0.007^{* *}$ & & $0.005^{* *}$ & & $0.010^{*}$ & \\
\hline & & & {$[0.001]$} & & {$[0.002]$} & \\
\hline & $(0.003)$ & & $(0.002)$ & & $(0.005)$ & \\
\hline \multirow[t]{2}{*}{ Industry Internet Use * Q1 } & & 0.006 & & $0.004 *$ & & $0.011 * *$ \\
\hline & & $(0.003)$ & & $\begin{array}{l}{[0.001]} \\
(0.002)\end{array}$ & & $\begin{array}{l}{[0.002]} \\
(0.005)\end{array}$ \\
\hline \multirow[t]{2}{*}{ Industry Internet Use * Q2 } & & 0.004 & & $\begin{array}{c}0.004 \\
{[0.000]}\end{array}$ & & $\begin{array}{c}0.008 \\
{[0.001]}\end{array}$ \\
\hline & & $(0.003)$ & & $(0.002)$ & & $(0.005)$ \\
\hline \multirow[t]{2}{*}{ Industry Internet Use * Q3 } & & $0.006^{*}$ & & $\begin{array}{l}0.005^{*} \\
{[0.001]}\end{array}$ & & $\begin{array}{l}0.010^{*} \\
{[0.002]}\end{array}$ \\
\hline & & $(0.003)$ & & $(0.002)$ & & $(0.005)$ \\
\hline \multirow[t]{2}{*}{ Industry Internet Use * Q4 } & & $0.008^{* *}$ & & $\begin{array}{c}0.006^{* * *} * \\
{[0.001]}\end{array}$ & & $\begin{array}{l}0.009 * \\
{[0.002]}\end{array}$ \\
\hline & & $(0.004)$ & & $(0.002)$ & & $(0.005)$ \\
\hline Firm-Level Controls & Yes & Yes & Yes & Yes & Yes & Yes \\
\hline Industry Fixed Effects & Yes & Yes & Yes & Yes & Yes & Yes \\
\hline Country-Year Fixed Effects & Yes & Yes & Yes & Yes & Yes & Yes \\
\hline $\begin{array}{l}\text { P-Value of Difference in Coefficients (Below } \\
\text { and Above Median) }\end{array}$ & 0.02 & & 0.02 & & 0.47 & \\
\hline \multicolumn{7}{|l|}{ P-Value of Difference in Coefficients (Between } \\
\hline Q1 and Q4) & & 0.12 & & 0.02 & & 0.40 \\
\hline Observations & 26,642 & 26,642 & 41,720 & 41,720 & 7,087 & 7,087 \\
\hline $\mathrm{R}^{2}$ & 0.46 & 0.46 & & & & \\
\hline Pseudo- $\mathrm{R}^{2}$ & & & 0.26 & 0.26 & 0.18 & 0.18 \\
\hline
\end{tabular}

Note: Firm-level controls are the same as those of column (5) of Panel A of Table 3. Robust standard errors clustered at country-industry-year level are shown in parentheses. For logistic regressions, marginal effects are reported in brackets. ***, ** and $*$ indicate significance at $1 \%, 5 \%$ and $10 \%$ confidence levels, respectively. 
Appendix Table 1: Observations by Country

\begin{tabular}{|c|c|c|c|c|c|c|c|c|}
\hline & & Percentage & & & Percentage & & & Percentage \\
\hline Country & Observations & $\begin{array}{c}\text { Share in } \\
\text { Total }\end{array}$ & Country & Observations & $\begin{array}{c}\text { Share in } \\
\text { Total }\end{array}$ & Country & Observations & $\begin{array}{c}\text { Share in } \\
\text { Total }\end{array}$ \\
\hline Albania & 199 & 0.40 & The Gambia & 153 & 0.31 & Pakistan & 843 & 1.69 \\
\hline Angola & 659 & 1.32 & Georgia & 243 & 0.49 & Panama & 587 & 1.17 \\
\hline Antigua and Barbuda & 116 & 0.23 & Ghana & 475 & 0.95 & Paraguay & 719 & 1.44 \\
\hline Argentina & 1,790 & 3.58 & Grenada & 129 & 0.26 & Peru & 1,464 & 2.93 \\
\hline Armenia & 262 & 0.52 & Guatemala & 858 & 1.72 & Philippines & 944 & 1.89 \\
\hline Azerbaijan & 291 & 0.58 & Guinea & 192 & 0.38 & Poland & 260 & 0.52 \\
\hline The Bahamas & 114 & 0.23 & Guinea-Bissau & 133 & 0.27 & Romania & 304 & 0.61 \\
\hline Barbados & 120 & 0.24 & Guyana & 136 & 0.27 & Russian Federation & 717 & 1.43 \\
\hline Belarus & 193 & 0.39 & Honduras & 595 & 1.19 & Rwanda & 183 & 0.37 \\
\hline Belize & 146 & 0.29 & Hungary & 248 & 0.50 & Samoa & 35 & 0.07 \\
\hline Benin & 90 & 0.18 & Indonesia & 1,122 & 2.24 & Senegal & 479 & 0.96 \\
\hline Bhutan & 215 & 0.43 & Iraq & 707 & 1.41 & Serbia & 327 & 0.65 \\
\hline Bolivia & 681 & 1.36 & Jamaica & 225 & 0.45 & Sierra Leone & 126 & 0.25 \\
\hline $\begin{array}{l}\text { Bosnia and } \\
\text { Herzegovina }\end{array}$ & 252 & 0.50 & Kazakhstan & 400 & 0.80 & Slovak Republic & 165 & 0.33 \\
\hline Botswana & 502 & 1.00 & Kenya & 636 & 1.27 & Slovenia & 243 & 0.49 \\
\hline Brazil & 1,077 & 2.15 & Kosovo & 200 & 0.40 & South Africa & 895 & 1.79 \\
\hline Bulgaria & 1,171 & 2.34 & Kyrgyz Republic & 154 & 0.31 & Sri Lanka & 462 & 0.92 \\
\hline Burkina Faso & 310 & 0.62 & Laos & 271 & 0.54 & St. Kitts and Nevis & 117 & 0.23 \\
\hline Burundi & 265 & 0.53 & Latvia & 211 & 0.42 & St. Lucia & 130 & 0.26 \\
\hline Cameroon & 320 & 0.64 & Lesotho & 88 & 0.18 & $\begin{array}{l}\text { St. Vincent and the } \\
\text { Grenadines }\end{array}$ & 129 & 0.26 \\
\hline Cape Verde & 96 & 0.19 & Liberia & 111 & 0.22 & Suriname & 152 & 0.30 \\
\hline $\begin{array}{l}\text { Central African } \\
\text { Republic }\end{array}$ & 135 & 0.27 & Lithuania & 209 & 0.42 & Swaziland & 259 & 0.52 \\
\hline Chad & 120 & 0.24 & Macedonia & 292 & 0.58 & Tajikistan & 247 & 0.49 \\
\hline Chile & 1,702 & 3.40 & Madagascar & 336 & 0.67 & Tanzania & 388 & 0.78 \\
\hline Colombia & 1,774 & 3.55 & Malawi & 83 & 0.17 & Timor-Leste & 82 & 0.16 \\
\hline $\begin{array}{l}\text { Democratic Republic } \\
\text { of the Congo }\end{array}$ & 517 & 1.03 & Mali & 654 & 1.31 & Togo & 102 & 0.20 \\
\hline $\begin{array}{l}\text { Republic of the } \\
\text { Congo }\end{array}$ & 91 & 0.18 & Mauritania & 214 & 0.43 & Tonga & 107 & 0.21 \\
\hline Costa Rica & 408 & 0.82 & Mauritius & 275 & 0.55 & $\begin{array}{l}\text { Trinidad and } \\
\text { Tobago }\end{array}$ & 308 & 0.62 \\
\hline Ivory Coast & 462 & 0.92 & Mexico & 2,454 & 4.91 & Turkey & 835 & 1.67 \\
\hline Croatia & 561 & 1.12 & Micronesia & 35 & 0.07 & Uganda & 515 & 1.03 \\
\hline Czech Republic & 165 & 0.33 & Moldova & 327 & 0.65 & Ukraine & 544 & 1.09 \\
\hline Dominica & 134 & 0.27 & Mongolia & 336 & 0.67 & Uruguay & 907 & 1.81 \\
\hline Dominican Republic & 289 & 0.58 & Montenegro & 60 & 0.12 & Uzbekistan & 320 & 0.64 \\
\hline Ecuador & 836 & 1.67 & Mozambique & 440 & 0.88 & Vanuatu & 81 & 0.16 \\
\hline El Salvador & 884 & 1.77 & Namibia & 307 & 0.61 & Venezuela & 158 & 0.32 \\
\hline Eritrea & 91 & 0.18 & Nepal & 328 & 0.66 & Vietnam & 953 & 1.91 \\
\hline Estonia & 232 & 0.46 & Nicaragua & 633 & 1.27 & Yemen & 300 & 0.60 \\
\hline Fiji & 47 & 0.09 & Niger & 85 & 0.17 & Zambia & 434 & 0.87 \\
\hline Gabon & 108 & 0.22 & Nigeria & 1,865 & 3.73 & Zimbabwe & 547 & 1.09 \\
\hline
\end{tabular}




\section{Appendix Table 2: Description of Variables Used}

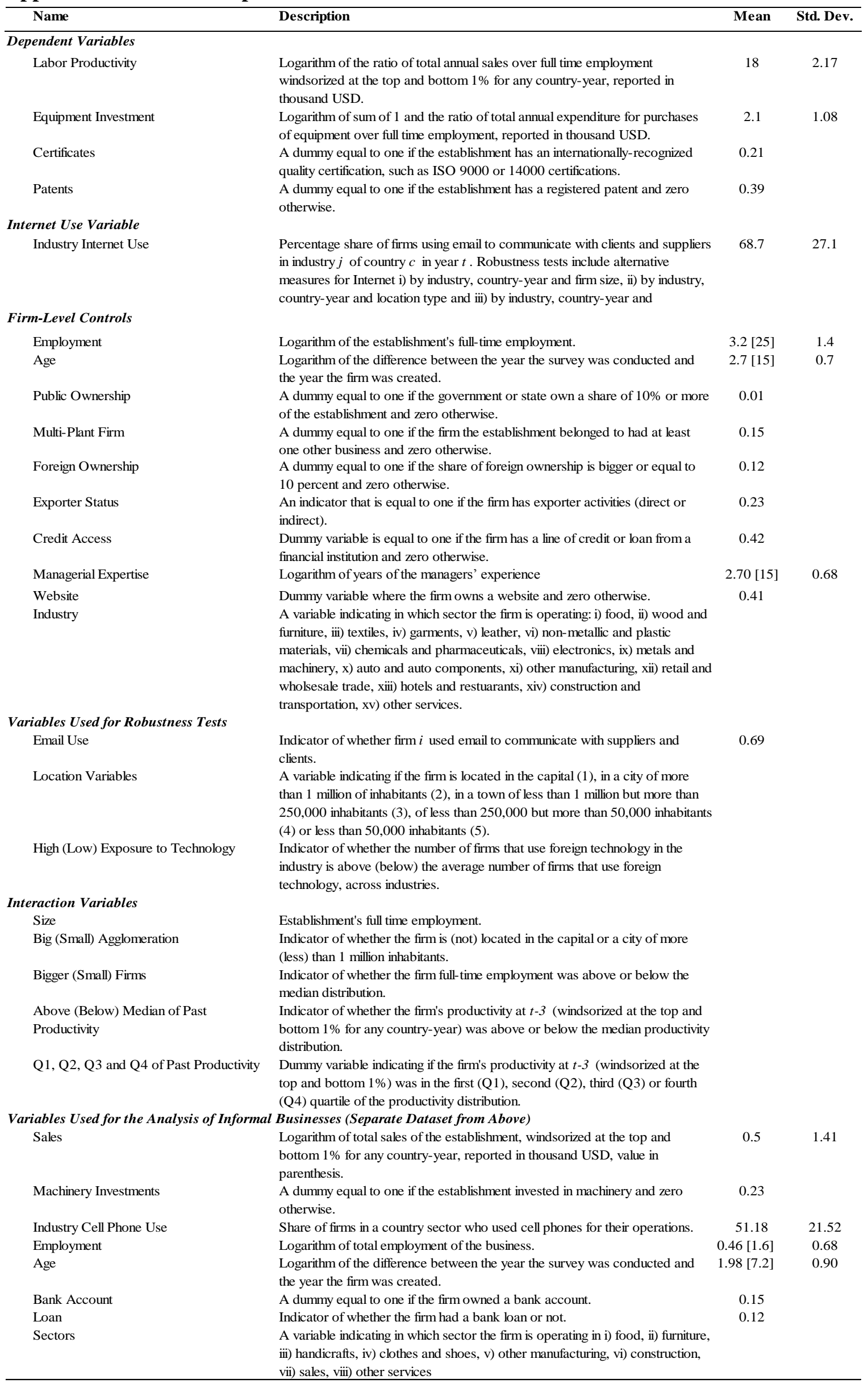




\section{Appendix Table 3: Robustness for Innovation Variables}

Panel A: Equipment Investment

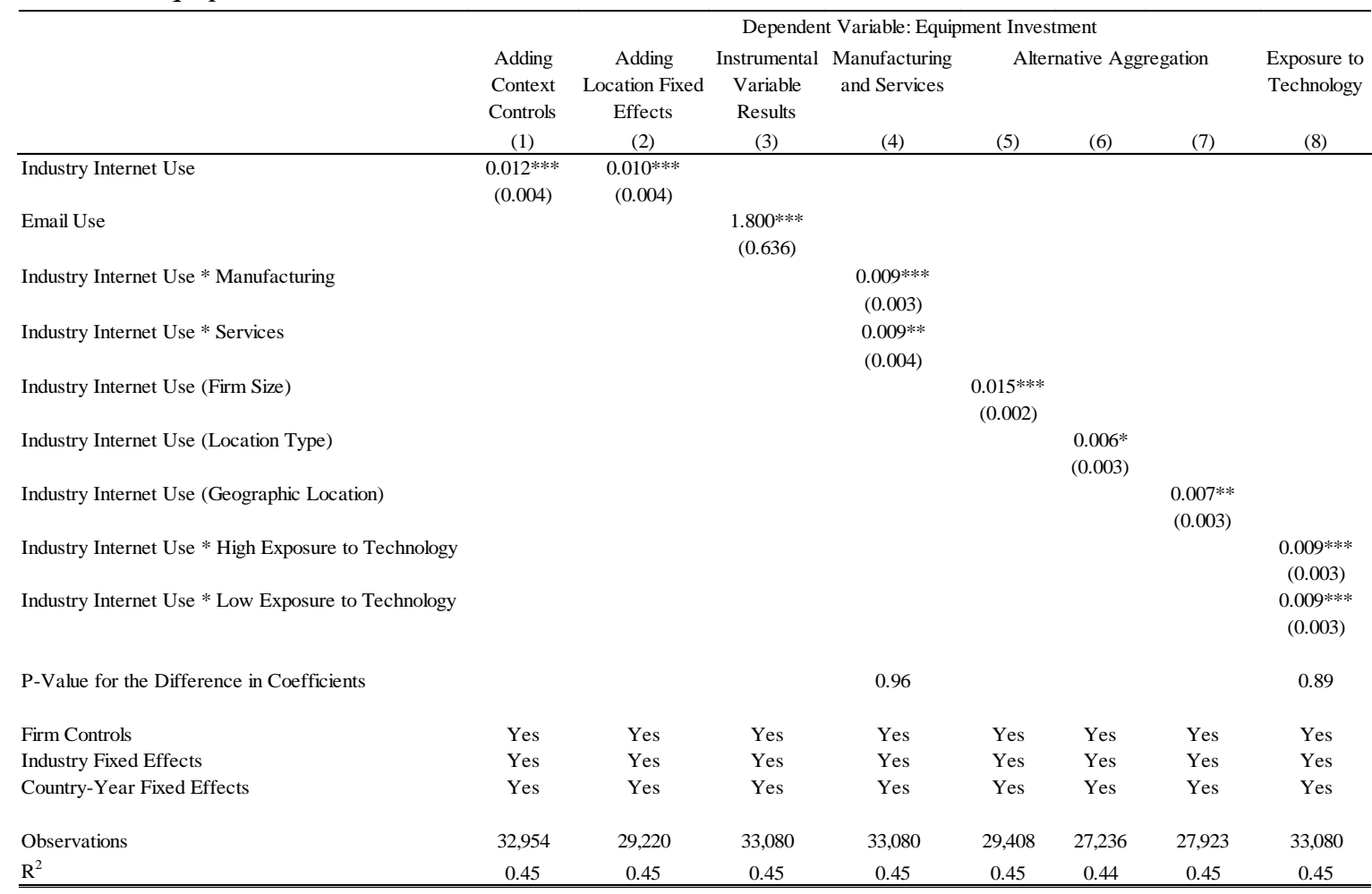

\section{Panel B: Quality Certificates}

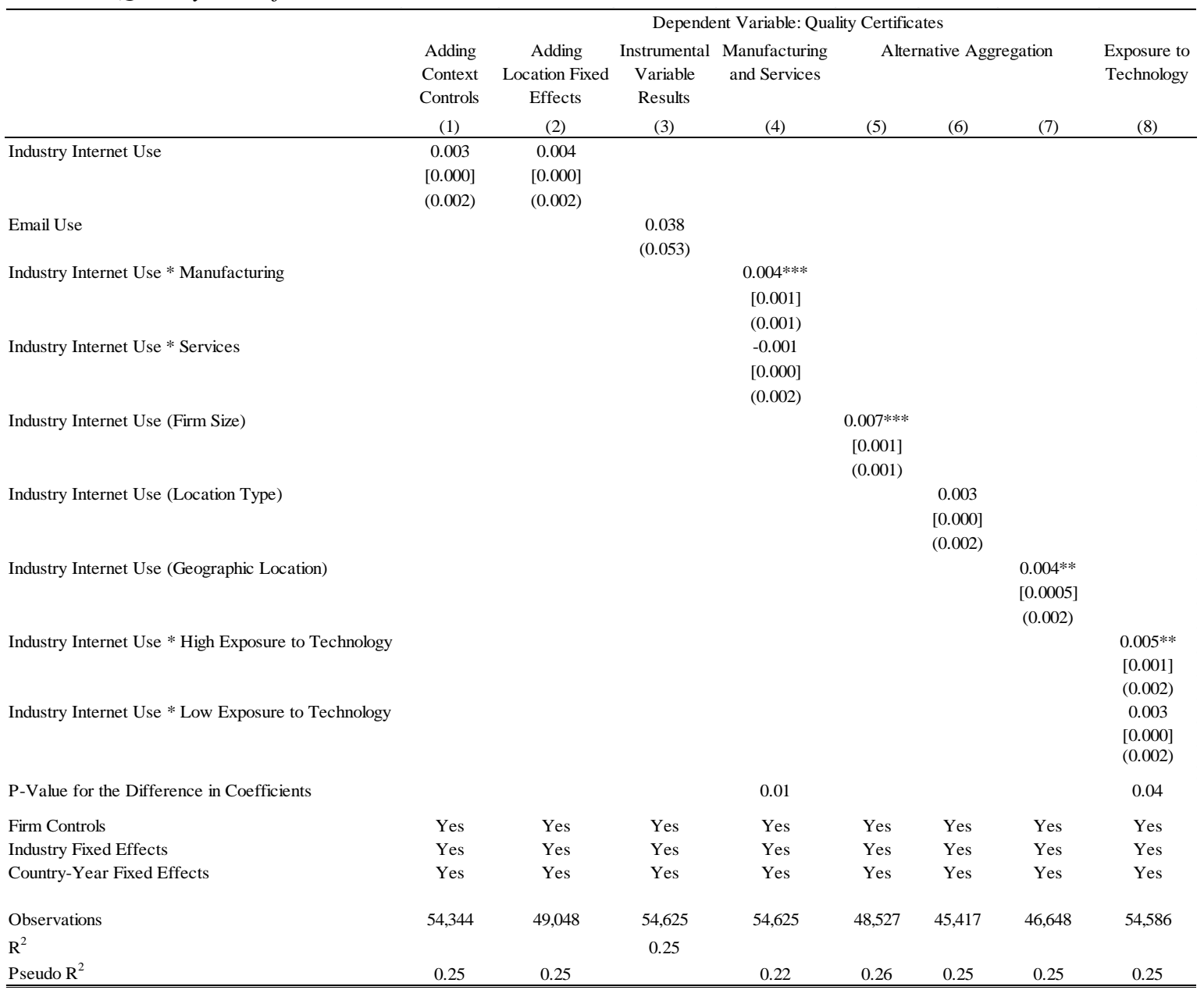




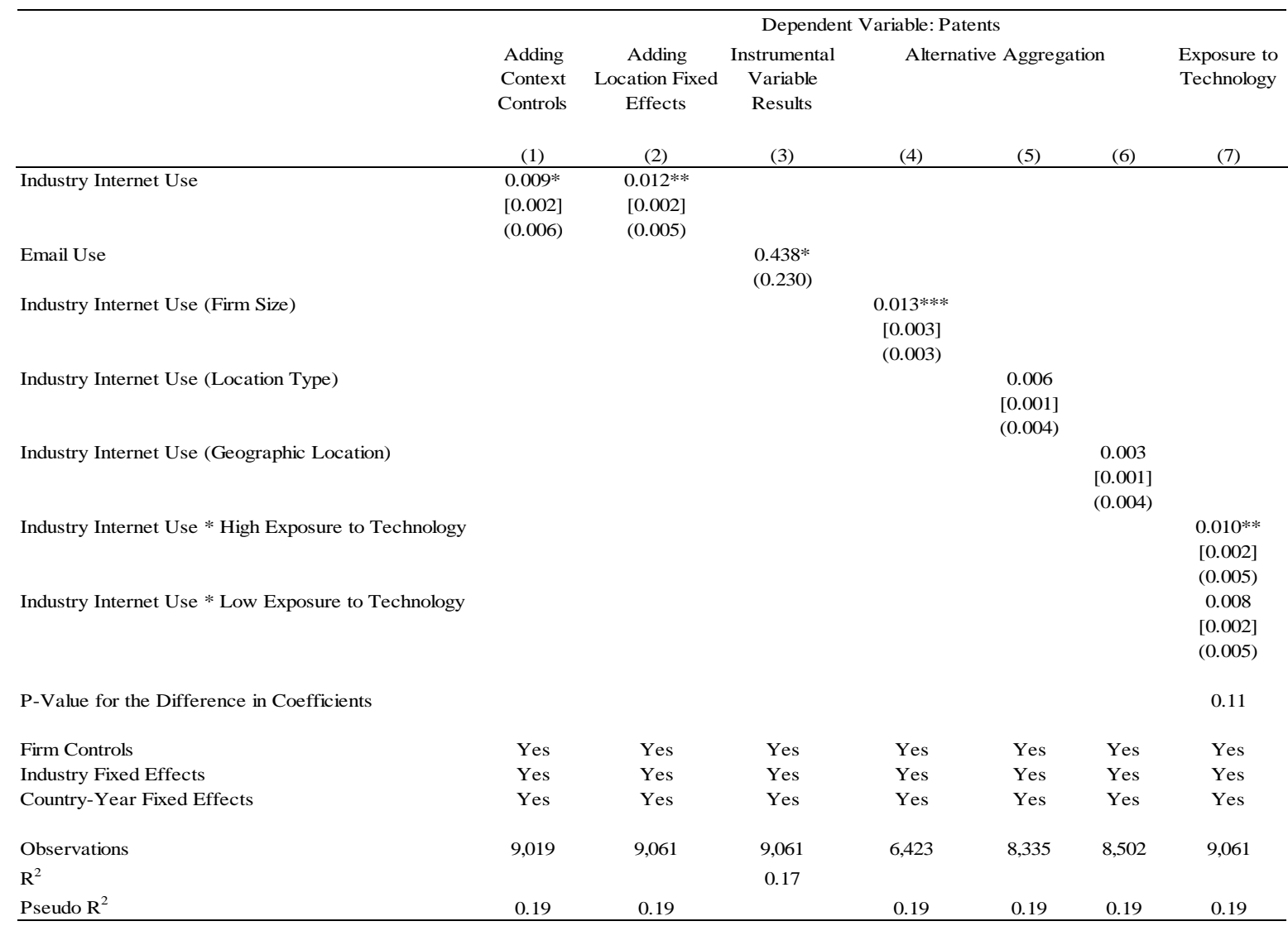

Note: Panel A reports results from ordinary least squares regressions while Panels B and C report results from logistic regressions. Firm-level controls are the same as those of column (5) of Panel A of Table 3. Robust standard errors clustered at country-industry-year level. For logistic regressions, marginal effects are reported in brackets. ***, ** and * indicate significance at $1 \%, 5 \%$ and $10 \%$ confidence levels, respectively. 


\section{The UNU-MERIT WORKING Paper Series}

2014-01 The medium-term effect of R\&D on firm growth by Marco Capasso, Tania Treibich and Bart Verspagen

2014-02 Diverse and uneven pathways towards transition to low carbon development: The case of diffusion of solar PV technology in ChinaMichiko lizuka

2014-03 User innovators and their influence on innovation activities of firms in Finland by JariKuusisto, MerviNiemi and Fred Gault

2014-04 Migration, remittances and household welfare in Ethiopia by Lisa Andersson

2014-05 Path-breaking directions of nanotechnology-based chemotherapy and molecular cancer therapy by Mario Coccia and Lili Wang

2014-06 Poor trends - The pace of poverty reduction after the Millennium Development AgendaRichard Bluhm, Denis de Crombrugghe, Adam Szirmai

2014-07 Firms' adoption of international standards: Evidence from the Ethiopian floriculture sector by MuluGebreeyesu

2014-08School choice, segregation, and forced school closureby Cheng Boon Ong andKristof De Witte

2014-09Gender difference in support for democracy in Sub-Saharan Africa: Do social institutions matter?by MatyKonte

2014-10 Why are women less democratic than men? Evidence from Sub-Saharan African countries by Cecilia García-Peñalosa and MatyKonte

2014-11 Tipping points? Ethnic composition change in Dutch big city neighbourhoods by Cheng Boon Ong

2014-12 Technology life cycle and specialization patterns of latecomer countries. The case of the semiconductor industry by Giorgio Triulzi

2014-13 Patents as quality signals? The implications for financing constraints on $R \& D$ by Dirk Czarnitzki, Bronwyn H. Hall and Hanna Hottenrott

2014-14 Assessment of effectiveness of Chinese aid in competence building and financing development in Sudan by SamiaSatti Osman Mohamed Nour

2014-15Education, training and skill development policies in Arab Gulf countries: Macromicro overview by SamiaSatti Osman Mohamed Nour

2014-16 Structure of labour market and unemployment in Sudan by SamiaSatti Osman Mohamed Nour

2014-17 Overview of knowledge transfer in MENA countries - The case of Egypt by SamiaSatti Osman Mohamed Nour

2014-18 The impact of ICT in public and private universities in Sudanby SamiaSatti Osman Mohamed Nour

2014-19End-user collaboration for process innovation in services: The role of internal resources by Mona Ashok, Rajneesh Narula and Andrea Martinez-Noya

2014-20 Public investment and regional politics: The case of Turkey by Mehmet Guney Celbis, Denis de Crombrugghe and Joan Muysken

2014-21 Infrastructure and the international export performance of Turkish regions by Mehmet Guney Celbis, Peter Nijkamp and Jacques Poot

2014-22 Discovering and explaining work-family strategies of parents in Luxembourg by Nevena Zhelyazkova

2014-23Parental leave take up and return to work of mothers in Luxembourg: An application of the model of nested dichotomies by Nevena Zhelyazkova 
2014-24 Millennium Development Goals: Tool or token of global social governance? by Mueid Al Raee, Elvis Amoateng, Elvis Korku Avenyo, Youssef Beshay, Mira Bierbaum, Charlotte Keijser and Rashmi Sinha

2014-25 One Europe or several? Causes and consequences of the European stagnation by Jan Fagerberg and Bart Verspagen

2014-26 The harmony of programs package: Quasi-experimental evidence on deworming and canteen interventions in rural Senegal by Théophile Azomahou, Fatoumata Diallo and Wladimir Raymond

2014-27 Country Terms of Trade 1960-2012: Trends, unit roots, over-differencing, endogeneity, time dummies, and heterogeneity by Thomas Ziesemer

2014-28 The structure and comparative advantages of China's scientific research Quantitative and qualitative perspectives by Lili Wang

2014-29 Transition to knowledge-based economy in Saudi Arabia by Samia Satti Osman Mohamed Nour

2014-30 Challenges and opportunities for transition to knowledge-based economy in Arab Gulf countries by Samia Satti Osman Mohamed Nour

2014-31 Migration of international students and mobilizing skills in the MENA Region by Samia Satti Osman Mohamed Nour

2014-32 Beyond product innovation; improving innovation policy support for SMEs in traditional industries by René Wintjes, David Douglas, Jon Fairburn, Hugo Hollanders and Geoffrey Pugh

2014-33 The impact of innovation support programmes on SME innovation in traditional manufacturing industries: an evaluation for seven EU regions by Dragana Radicic, Geoffrey Pugh, Hugo Hollanders and René Wintjes

2014-34 Beliefs dynamics in communication networks by Théophile T. Azomahou and Daniel C. Opolot

2014-35 Stability and strategic diffusion in networks by Théophile T. Azomahou and Daniel C. Opolot

2014-36 Epsilon-stability and the speed of learning in network games by Théophile T. Azomahou and Daniel C. Opolot

2014-37 Afghan unaccompanied minors in the Netherlands: Far away from home and protected? by Carla Buil and Melissa Siegel

2014-38Multinational production and trade in an endogenous growth model with heterogeneous firms by Hibret B. Maemir and Thomas Ziesemer

2014-39 The political economy of research and innovation in organic photovoltaics (OPV) in different world regions by Serdar Türkeli and René Kemp

2014-40 Towards the societal system of innovation: The case of metropolitan areas in Europe by Serdar Türkeli and René Wintjes

2014-41 To return permanently or to return temporarily? Explaining migrants' intentions by Özge Bilgili and Melissa Siegel

2014-42 Catching up and lagging behind in a balance-of-payments-constrained dual economy by Alejandro Lavopa

2014-43 An introduction to the economics of rare earths by Eva Bartekova

2014-44 The unequal effect of India's industrial liberalization on firms' decision to innovate: Do business conditions matter? By Maria Bas and Caroline Paunov

2014-45 Insurgents in motion: Counterinsurgency and insurgency relocation in Iraq by Puihang Wong 
2014-46 Successive leadership changes in the regional jet industry by Daniel Vertesy

2014-47 Demand, credit and macroeconomic dynamics: A microsimulation model by Huub Meijers, Önder Nomaler and Bart Verspagen

2014-48Accessibility analysis as an urban planning tool: Gas station location by D.A. Escobar , C. Cadena-Gaitán, F.J. Garcia

2014-49 China's economic embrace of Africa - An international comparative perspective by Tobias Broich and Adam Szirmai

2014-50 Mapping regional social enterprise ecosystems in India: Framework and indicators by Lina Sonne

2014-51Does shelter assistance reduce poverty in Afghanistan? By Craig Loschmann, Christopher R. Parsons and Melissa Siegel

2014-52 How important is innovation? A Bayesian factor-augmented productivity model on panel data by Georges Bresson, Jean-Michel Etienne and Pierre Mohnen

2014-53 Does too much work hamper innovation? Evidence for diminishing returns of work hours for patent grants by Mehmet Güney Celbi, Serdar Türkeli

2014-54 Globalization, the rise of biotechnology and catching up in agricultural innovation: The case of Bt technology in India Michiko lizuka and Ajay Thutupalli

2014-55 Where are innovation indicators, and their applications, going? by Fred Gault

2014-56 Productivity in services in Latin America and the Caribbean by Elena Arias-Ortiz, Gustavo Crespi, Alejandro Rasteletti and Fernando Vargas

2014-57 Optimal public investment, growth, and consumption: Fresh evidence from African countries by Augustin Kwasi Fosu, Yoseph Yilma Getachew and Thomas H.W. Ziesemer

2014-58 International R\&D alliances by firms: Origins and development by Rajneesh Narula and Andrea Martínez-Noya

2014-59 Appropriability mechanisms, innovation and productivity: Evidence from the UK by Bronwyn H. Hall and Vania Sena

2014-60 The size of patent categories: USPTO 1976-2006 by François Lafond

2014-61Asset recombination in international partnerships as a source of improved innovation capabilities in China by Simon C. Collinson and Rajneesh Narula

2014-62 The viability of sustained growth by India's MNEs: India's dual economy and constraints from location assets by Rajneesh Narula

2014-63 The effect of unconditional cash transfers on adult labour supply: A unitary discrete choice model for the case of Ecuador by Andrés Mideros and Cathal O'Donoghue

2014-64 Giving in South Africa: Determining the influence of altruism, inequality aversion and social capital by Nyasha Tirivayi

2014-65 The impact of food transfers for people living with HIV/AIDS: Evidence from Zambia by Nyasha Tirivayi and Wim Groot

2014-66 Size and economies of scale in higher education and the implications for mergers by Nyasha Tirivayi, Henriette Maasen van den Brink and Wim Groot

2014-67 Widowhood and barriers to seeking health care in Uganda by Nyasha Tirivayi

2014-68 An individual-centered approach to multidimensional poverty: The cases of Chile, Colombia, Ecuador and Peru by Andrea Franco Correa

2014-69 Innovation and productivity in services: Empirical evidence from Latin America by Gustavo Crespi, Ezequiel Tacsir and Fernando Vargas

2014-70 Analysing global value chains using input-output economics: Proceed with care by Önder Nomaler and Bart Verspagen 
2014-71 The deposit financing gap: Another Dutch disease by Huub Meijers, Joan Muysken and Olaf Sleijpen

2014-72 Do remittances and social assistance have different impacts on expenditure patterns of recipient households? The Moldovan case by Jennifer Waidler, Jessica Hagen-Zanker, Franziska Gassmann and Melissa Siegel

2014-73 The role of industry and economic context in open innovation: Evidence from Nigeria by Abiodun Egbetokun, Omolayo Oluwatope, David Adeyeye and Maruf Sanni

2014-74 Means to improve access to justice and legally empower victims of domestic violence: An empirical legal study on legislation and legal offices in Buenos Aires, Argentina by Julieta Marotta

2014-75 Do remittances not promote growth? A bias-adjusted three-step mixture-ofregressions by Maty Konte

2014-76Structural modernization and development traps: An empirical approach by Alejandro Lavopa and Adam Szirmai

2014-77Democratizing intellectual property systems: How corruption hinders equal opportunities for firms by Caroline Paunov

2014-78 Can internet infrastructure help reduce regional disparities? Evidence from Turkey by Mehmet Guney Celbis and Denis de Crombrugghe

2014-79 Obesity of women in Jordan - Prevalence and associated factors: Making a case for a comprehensive obesity policy by Sebastian Göllner and Zina Nimeh

2014-80 International R\&D spillovers and business service innovation by Neil FosterMcGregor, Johannes Pöschl and Robert Stehrer

2014-81 Tax incentives and firm size: effects on private R\&D investment in Spain by José M. Labeaga, Ester Martínez-Ros and Pierre Mohnen

2014-82 The Republic of Open Science: The institution's historical origins and prospects for continued vitality by Paul A. David

2014-83 How can political trust be built after civil wars? Lessons from post-conflict Sierra Leone by Pui-Hang Wong

2014-84 Has the internet fostered inclusive innovation in the developing world? by Caroline Paunov and Valentina Rollo 